\title{
Environmental risk assessment of the intake of contaminants in aquifers in the vicinity of a reclaimed waste dumpsite in Owerri municipal, Southeastern Nigeria
}

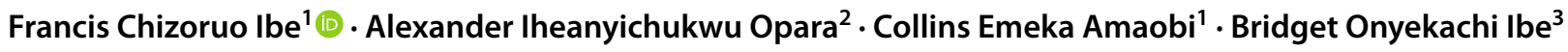

Received: 26 December 2019 / Accepted: 26 December 2020 / Published online: 18 January 2021

(c) The Author(s) 2021

\begin{abstract}
The study investigated groundwater sources within reclaimed municipal waste dumpsites around Akachi road in Owerri, Southeastern Nigeria. The research evaluated the pollution and risk inherent in the consumption of groundwater in the vicinity of the reclaimed waste dumpsite using standard procedures. Results showed acidic $\mathrm{pH}$ values for some groundwater samples within the reclaimed waste dumpsite. Elevated nitrate $\left(\mathrm{NO}_{3}{ }^{-}\right)$, aluminium $(\mathrm{Al})$ and chromium $(\mathrm{Cr})$ concentrations above the World Health Organization (WHO) limits for drinking water samples were recorded in some of the groundwater samples from the study area. The observed strong positive correlations between the metallic contaminants indicated that the distribution of the pollutants has a strong relationship with organic contaminants in the reclaimed waste dumpsite. Low contamination factor was exhibited by all metals for the individual samples except for $\mathrm{Cr}$ in sample $\mathrm{A}$ and $\mathrm{Al}$ in sample $\mathrm{A}$ and D. The pollution load index for all the samples was low, except for sample $\mathrm{C}$ with a pollution load index of unity. Elevated hazard quotient $>1$ and hazard index $>1$ were observed for both adults and children due to high Cr levels. The chronic daily intake risk assessment revealed values $<1$, while carcinogenic risk values greater than $10^{-6}$ and $10^{-4}$ were observed for the samples suggesting potential health risk for children and adults. The water quality index of samples from the reclaimed waste dumpsite calls for concern due to elevated levels of $\mathrm{Al}$ and $\mathrm{Cr}$. These findings, therefore, suggest the need to treat the groundwater from the reclaimed dumpsite before consumption to avert serious health risks. Finally, waste dumpsites should be remediated or allow to undergo natural remediation before reclamation, erecting residential structures, and sinking of boreholes for water supply within such areas.
\end{abstract}

Keywords Risk assessment $\cdot$ Waste dumpsite $\cdot$ Contaminants $\cdot$ Metallic pollutants $\cdot$ Aquifers

\section{Introduction}

Management of solid waste and disposal sites is a serious ecological concern all over the world (Vincent et al. 2012), due to the tendency of such dumpsites to contaminate ground and surface water sources (Ejiogu et al. 2017). Lack of proper waste management and disposal system is

Francis Chizoruo Ibe

francispavo@yahoo.com

1 Department of Chemistry, Imo State University, Owerri P.M.B. 2000, Imo State, Nigeria

2 Department of Geosciences, Federal University of Technology, Owerri P.M.B. 1526, Imo State, Nigeria

3 Department of Health Education, Alvan Ikoku Federal College of Education Owerri, Owerri, Imo State, Nigeria an unavoidable problem in most developing countries like Nigeria due to the increasing population, rapid urbanization, industrialization, and lax environmental laws (Okere et al. 2018). The waste management practises within the study area are simply based on the collection and dumping out of the city boundaries in open excavated waste dumps (Arukwe et al. 2012). This consequently results in irregular disposal of waste thereby creating major waste dumpsites in many parts of the city (Ikem et al. 2002). The waste dumpsites form a major breeding grounds for micro-organisms and other disease vectors like rats which put the health of the inhabitants at risk (Adewuyi and Opasina 2010; Bellebaum 2005). This is in addition to air pollution which results from offensive odour and uncontrolled burning of these wastes, which may jeopardize human health and deteriorate the air quality of the area (Enyoh et al., 2019; Ibe et al. 2016; Ibe et al. 2020a, b; Njoku et al. 2016; Opara et al. 2016). Due 
to different components of municipal wastes, the dumpsites may contain heavy metals as well as other pollutants that generally infiltrate into the groundwater system, thereby posing a great risk to the human population when such water is consumed (Obasi et al. 2015). Documented pieces of evidence have shown that improperly managed waste dumpsites are inimical to human health and has shown their possibility of contaminating the soil and underlying aquifers (Amadi et al. 2012; Boateng et al. 2019; David and Oluyege 2014; Ibe et al. 2017, 2018; Muze et al. 2020; Obasi et al. 2017; Temilola et al. 2014). This arises from leachate infiltration aided by intense precipitation into the surroundings which subsequently contaminate the soil as well as the groundwater systems (Mor et al. 2006; Taylor and Allen2006; Teta and Hikwa 2017). This is possible due to vertical and lateral migration of the pollutants which could threaten the health and life of animals and humans (Bukar et al. 2012; Ibe et al. 2019a).

It has been reported that consumption of contaminated groundwater could result in the weakening of human health, heart problems as well as other health abnormalities ( $\mathrm{Su}$ 2008). The risk of the onset of cancer and skin lesions have been reported in arsenic-contaminated groundwater (Smith et al. 2000). Studies have also shown that exposure to constituents of leachates from waste dumpsites above a certain threshold may be linked to an over abundance of bioaccumulated metallic components. These components are associated with heavy metal related poisoning symptoms and ailments such as vomiting and convulsion, asthma, hypertension, renal and cardiovascular diseases, ataxia, neurological illness, gastrointestinal problems, pneumonitis, cancer, skeletal deformities, anaemia, and diarrhea (Abarikwu et al. 2013; Farombi et al. 2012; Vrijheid 2000).

The importance of this study lies in the fact that most developing countries like Nigeria and Africa in general lack adequate supply of potable water due to poor sanitation, which results in ill health and death of many children under the age of five years (FRN 2000; WHO/UNICEF 2000). Therefore, a greater number of the population living in urban centres, semi-urban, and rural areas in Imo State and Nigeria at large depends solely on underground water sources like boreholes for domestic uses as well as for irrigation and industrial purposes (Longe et al. 2010; Pat-Mbano et al. 2010). This is unfortunately due to the inability of government agencies to provide pipe born water to the majority of the households (Chukwu 2015; FRN 2000; Ishaku et al. 2011). The demand and significance of groundwater supply have continued to increase tremendously as a result of climatic factors (De Giglio et al. 2015; Kumar 2012). This has continued to increase due to the contamination and alteration of this all-important resource as a result of anthropogenic factors such as urbanization, industrialization, and population growth (Obeta 2017). Another issue that calls for regular risk assessment of groundwater sources especially in Owerri Municipal is that most of the open waste dumpsites are located in the proximity of residential areas and some cases around wetlands (Abdus-Salam et al. 2011). Thus, the surface, as well as the groundwater sources are rendered unwholesome, since the waste dumpsites have no basement or thick shale lining to selectively absorb some of the contaminants in the leachates (Ikem et al. 2002; Teta and Hikwa 2017). As a result of these factors, most underground water studies conducted in Owerri and its environs have revealed low pH (Duru et al. 2017a, 2019; Ekeleme et al. 2014), high electrical conductivity (Ijeh 2014a), and heavy metal levels above tolerable limits (Duru et al. 2019; Ejiogu et al. 2017; Ogoko 2017). Also, the previous report of trace metal analysis of soil and edible plant leaves from the reclaimed waste dumpsite under investigation by the authors revealed the presence of aluminium, chromium, copper, iron, manganese, and zinc (Ibe et al. 2017). Moreover, no other documented report has used all the pollution risk assessment models to study groundwater sources such as boreholes in the area.

The present study, therefore, investigated the risk inherent in the consumption of groundwater sources like boreholes within the reclaimed waste dumpsite around Akachi Road in Owerri Municipality, Nigeria. To achieve this, borehole water samples were collected in the vicinity of the reclaimed waste dumpsite and analyzed for the presence of contaminants. Pollution risk assessments were carried out using contamination factor (CF), pollution load index (PLI), water quality index (WQI), hazard quotient (HQ), hazard index (HI), chronic daily intake (CDI) of metal contaminants, carcinogenic risk (CR), and human exposure due to ingestion $\left(\operatorname{Exp}_{\mathrm{ing}}\right)$ of the groundwater from the reclaimed waste dumpsite.

\section{Materials and methods}

\section{Study location}

The map of the study location is presented in Fig. 1a, b. The investigation was carried out in Owerri Municipal, the capital city of Imo state, which is located in the eastern part of Nigeria. Owerri Municipal lies within the coordinates defined by longitudes $6^{\circ} 50^{\prime} \mathrm{E}-7^{\circ} 25^{\prime} \mathrm{E}$ and latitudes $4^{\circ} 23^{\prime} \mathrm{N}-7^{\circ} 15^{\prime} \mathrm{N}$. The city has a population of 125,337 according to the 2006 population census (FRN 2007). The demographic information was projected at 200,413 in 2010 (NBS 2011), with these statistics believed to have increased significantly after a decade. The reclaimed waste dump site is located at Akachi Road, Owerri, Imo State, Nigeria, as shown in Figs. 1a, b, Fig. 2a, b. The site was abandoned for more than 10 years before being reclaimed with the majority of the wastes being buried in the soil. The area was 


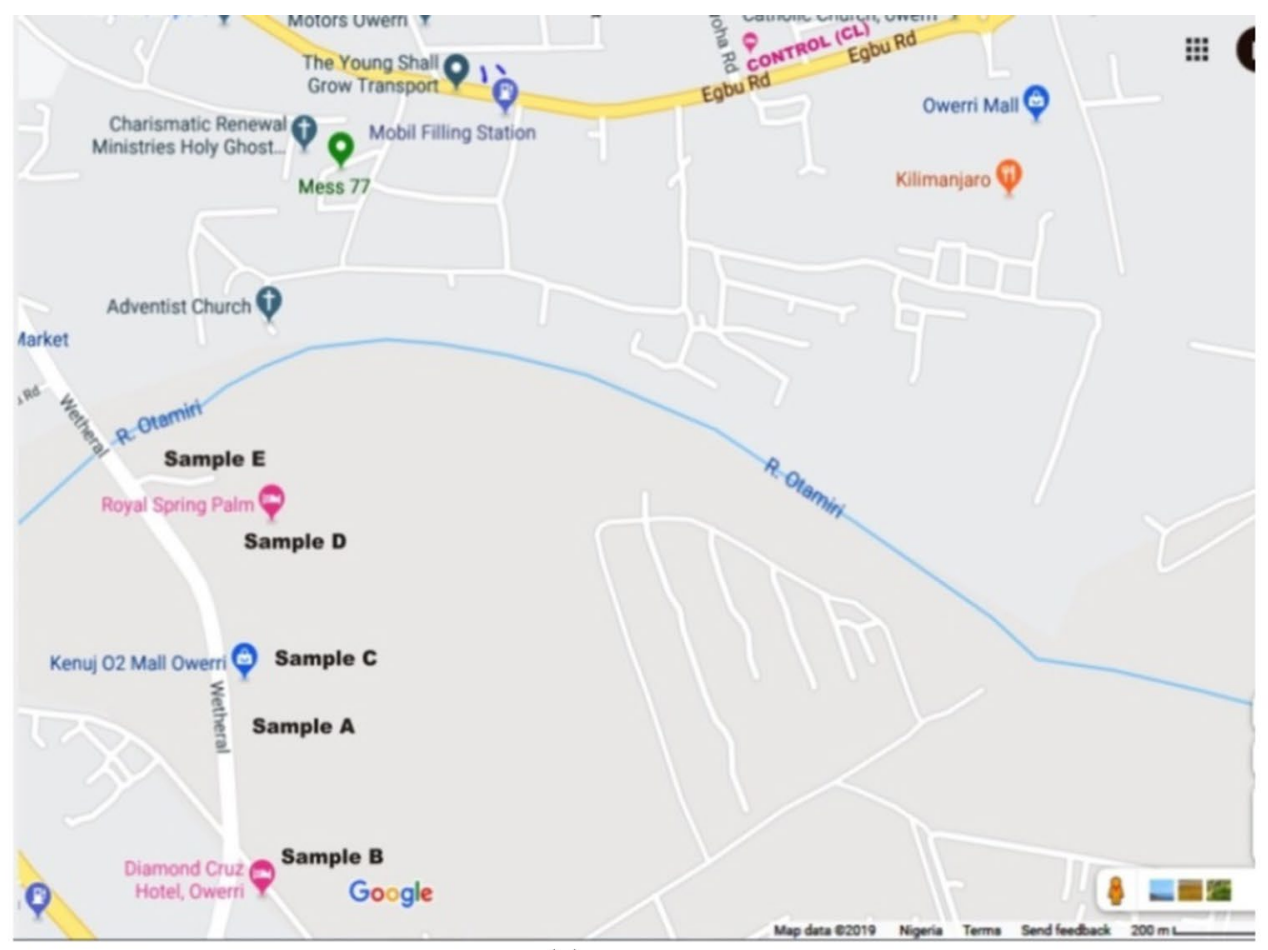

(a)

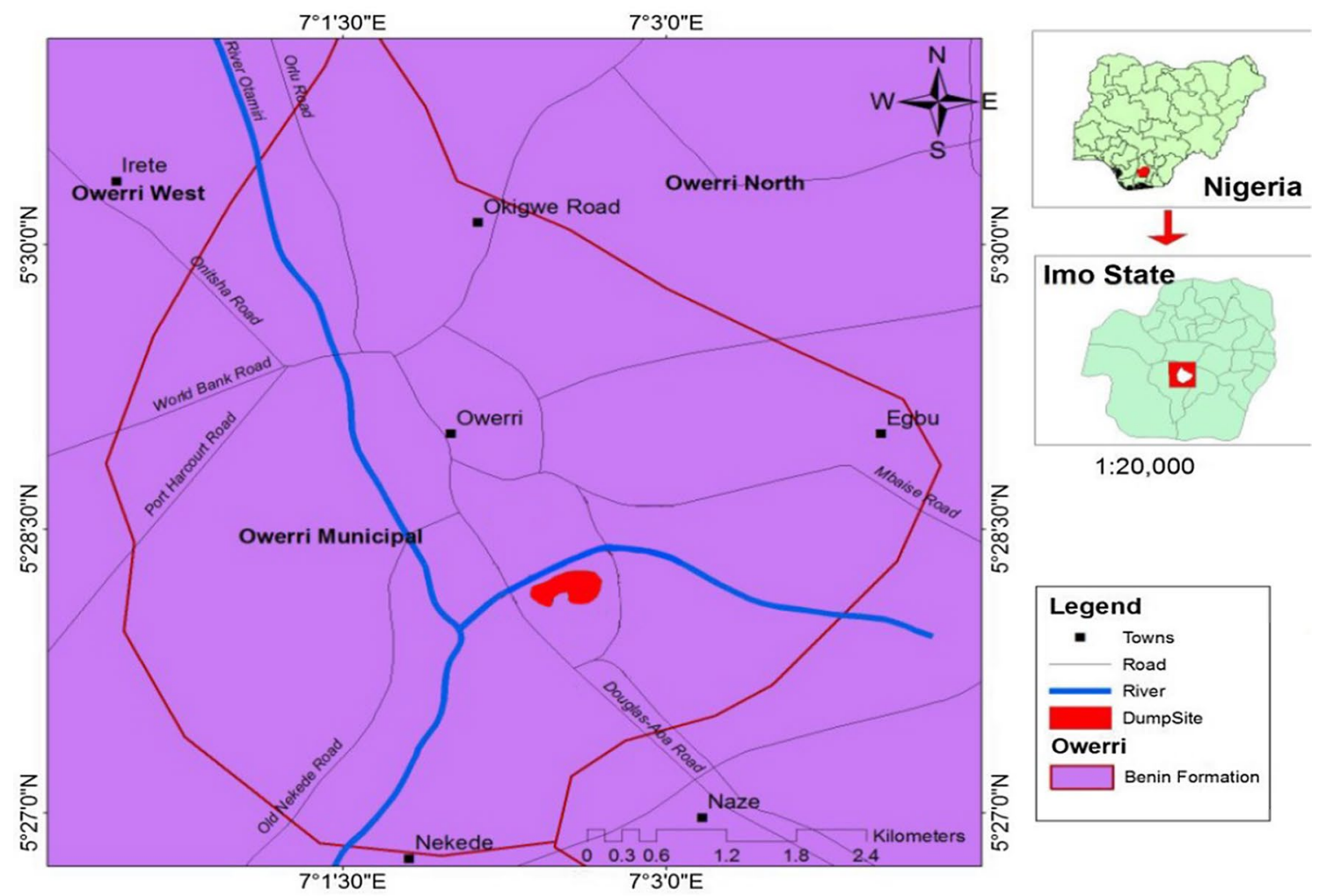

(b)

Fig. 1 a Google map of study location. b Geological map of Owerri and environs showing the reclaimed dumpsite. *Ibe et al. (2017) 


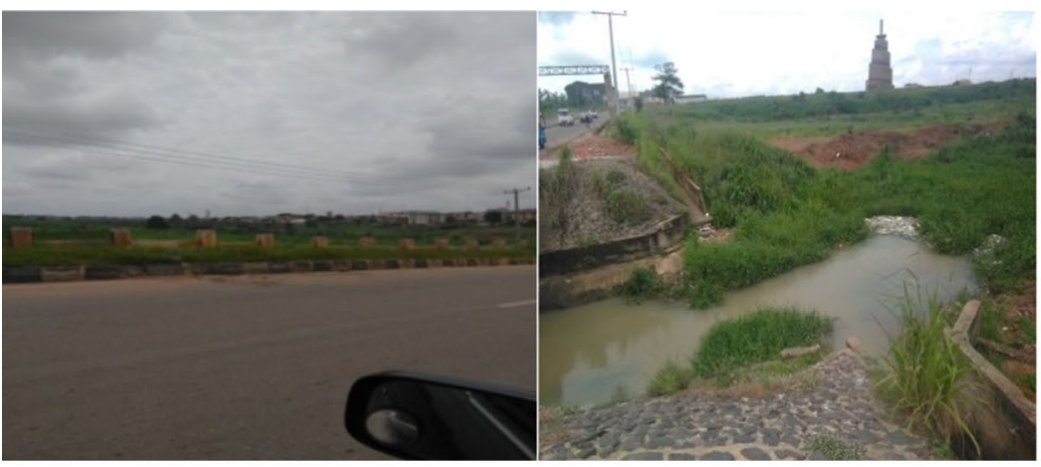

(a)

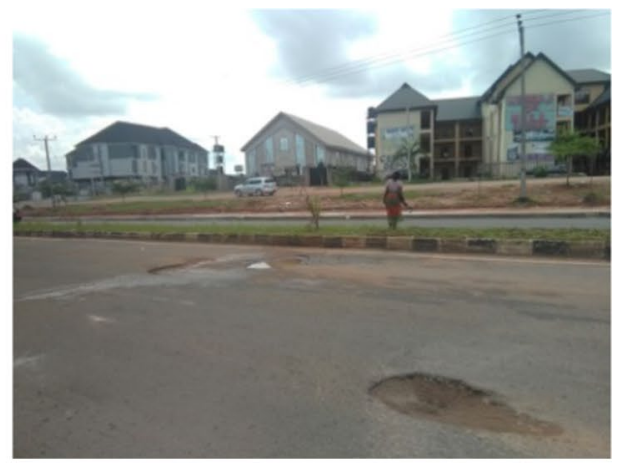

(b)

Fig. 2 a undeveloped section of the reclaimed dumpsite, $\mathbf{b}$ developed section of the reclaimed dumpsite along Akachi Road

opened up following the construction of a bypass known as Akachi Road across the reclaimed waste dump site (Fig. 2a, b). Residential and commercial buildings like shopping malls, hotels, and stores were subsequently erected on this reclaimed dumpsite. Most of these residential and commercial buildings dug their boreholes with overhead storage tanks to provide water for their domestic and commercial uses. So, all the inhabitants of this area depend on these boreholes drilled in the reclaimed dumpsite for domestic water uses since there is presently no public water supply in the area and the city in general. This development, therefore, calls for concern and pollution risk assessment which the inhabitants are exposed to when groundwater sources in this area are consumed.

\section{Climate and geology of the study area}

The weather condition of the area is occasioned by the varying high temperature which shows seasonally distributed rainfall. The study area has a bi-modal climate made up of the dry and wet seasons. March signals the beginning of the wet season which ends in early October, while the dry period starts from the end of October up to the early part of March. Intense sunlight is usually observed between November and December which lasts up to February. Shorter sunlight hours are observed in the wet period between May and October.

Daylight temperatures in the area ranged from 18 up to $34{ }^{\circ} \mathrm{C}$, with the average daily minimum and maximum temperatures of 19 and $28{ }^{\circ} \mathrm{C}$, respectively (Akinsanola and Ogunjobi 2014). The approximated evapotranspiration rate in the area is between 1450 and $1460 \mathrm{~mm}$ /year (Chineke et al. 2011). Rainfall is a critical climatic factor in pollution studies with far-reaching ecological consequences. The rainy period is controlled by the advance of northward maritime air which is linked to the Atlantic Ocean. The months of July and August are the wettest seasons in this area. There is usually an alternating period of sunshine and rainfall situations due to the conventional nature of the heavy downpour. The wet period usually begins from March to October with the mean yearly rainfall estimated at $2500-4000 \mathrm{~mm}$. About $89 \%$ of the rainfall is witnessed between May and October (Okoro et al. 2014, 2019). The regularity and intensity of the rainfalls result in massive runoff occasioned by the presence of steep slopes which renders the area vulnerable to flooding. Sometimes, the intense rainstorm events go with enormous flooding which causes leaching of the topsoil that subsequently infiltrate into the underground water (Ibe 1999; Ibe et al. 2018).

A comprehensive report of the geological and geomorphological study of the area has been previously documented (Onyeagocha 1980). Stratigraphically, the location and the surrounding areas are underlain by the Benin Formation (Fig. 1b). The Benin Formation is mostly made of sands, sandstones, and occasionally clays. These clays occur as intercalations with the largely massive sandstone beds with the thickness of the clay units increasing with depth. Texturally, the sands and sandstones are finely separated particles that range in size from fine to coarse sediment particles. Sands in the area have variegated colours, unattached and crumbly, with highly ferruginous sandstone in some places. The formation has a varying thickness of about $2000 \mathrm{~m}$ (Uma 1989). The Benin Formation is poorly compacted with high porosity and permeability (Onyeagocha 1980). Therefore, absorptivity, spread-ability, and storability of groundwater and other fluids are usually elevated due to the sand component which forms over $90 \%$ of the formation in the area (Ijeh 2014b; Uma 1989). Usually, the safety and protective capacity of the aquiferous units are determined by the geologic formations in addition to other factors. The susceptibility of the groundwater to surficial contamination is influenced by certain factors such as lithology of the overlying formations as well as the hydraulic properties (Ijeh and Onu 2012). The high porosity, transmissivity, permeability, and elevated hydraulic attributes of the Benin Formation renders the aquifers in the study area vulnerable to percolation and 
infiltration by contaminants from the waste dumpsite (Ibe 1999; Okiongbo and Akpofure 2012).

\section{Sample collection and analysis}

Groundwater samples were collected from five different boreholes within the reclaimed waste dumpsite as indicated in Table 1 and Fig. 1a. The borehole water samples were collected within July 2018 using previously cleaned plastic containers. At each point of the sample collection, the container was rinsed twice with the water sample to be collected. Borehole water samples collected from the reclaimed waste dumpsite were labelled A-E. Another set of borehole water samples were collected from Ouspuc avenue, Alaubi layout Egbu in Owerri North LGA, Imo State, to serve as the control as shown in Table 1 and Fig. 1a. The borehole water sample points were geo-referenced using the Garmin GPSmap 76.

The physicochemical parameters including temperature (T), electrical conductivity (EC), $\mathrm{pH}$, total dissolved solids (TDS), phosphate $\left(\mathrm{PO}_{4}{ }^{-3}\right)$, sulphate $\left(\mathrm{SO}_{4}{ }^{-2}\right)$, and nitrate $\left(\mathrm{NO}_{3}{ }^{-}\right)$were determined for the groundwater samples. The concentrations of the metallic elements which include aluminium (Al), chromium $(\mathrm{Cr})$, copper $(\mathrm{Cu})$, Iron $(\mathrm{Fe})$, manganese $(\mathrm{Mn})$, and zinc $(\mathrm{Zn})$ were also determined in the water samples. At each sample point, the temperature was determined with the aid of the LCD portable digital multistem $\left(-50\right.$ to $150{ }^{\circ} \mathrm{C}$ ) centigrade thermometer, while the pH was determined with the Hanna $\mathrm{pH}$ metre Hi 98,107. The electrical conductivity and total dissolved solids (TDS) were determined using a portable digital EC/TDS metre (Ketotek). The concentrations of the anions in the groundwater samples were determined in the laboratory using Hanna Hi 83,200 Multi-parameter bench photometer. Nitrate in the samples was determined using cadmium reduction with Hanna H1 83,200 multi-parameter bench photometer at $525 \mathrm{~nm} .10 \mathrm{~mL}$ of each water sample was transferred into two separate sample cells, with one as a blank to zero the instrument. Nitrate reagent was introduced into the second one, placed into the sample cell compartment, and allowed for $4 \mathrm{~min}$ and $30 \mathrm{~s}$ for the nitrate concentration $(\mathrm{mg} / \mathrm{L})$ in the sample to be displayed. Determination of phosphate was by the amino acid method with the aid of the Hanna H1 83,200 multi-parameter bench photometer at $525 \mathrm{~nm}$. 10 drops of molybdate reagent and phosphate $\mathrm{HR}$ reagent $\mathrm{B}$ was added to the sample cell containing $10 \mathrm{~mL}$ of the water sample, while a second sample containing water to be analyzed was used to zero the instrument. The mixture was allowed to dissolve by shaking gently, inserted into the cell compartment, and phosphate concentration $(\mathrm{mg} / \mathrm{L})$ taken after 5 min. The Turbidimetric method using Hanna H1 83,200 multi-parameter bench photometer at $466 \mathrm{~nm}$ was used in the determination of sulphate levels in the water samples. $10 \mathrm{~mL}$ of the sample contained in two separate sample cells with one containing suphate reagent and the second one to zero the photometer. This was placed in the cell compartment, allowed for $5 \mathrm{~min}$ and sulphate concentration $(\mathrm{mg} / \mathrm{L})$ displayed (Duru et al. 2019; Ibe and Ibe 2016). Water samples for metallic content analysis were preserved with two drops of $2 \mathrm{M} \mathrm{HNO}_{3} .50 \mathrm{~mL}$ of each groundwater samples were digested with $5 \mathrm{~mL}$ of a concentrated solution of $\mathrm{HNO}_{3}$ acid in a beaker and heated on a hot plate. The heating was discontinued when the volume of the mixture reduced to $20 \mathrm{~mL}$, filtered with a Whatman filter paper into a $100 \mathrm{~mL}$ volumetric flask and made up to the mark with deionized water. The concentrations of the metals were determined with the atomic absorption spectrophotometer (AAS), Agilent 240FS AA model (USA).

\section{Quality control}

Reagents used throughout the experiments were of highquality analytical grade, which was purchased from BDH Chemical Ltd, UK, and Sigma- Aldrich Chemie GmbH,

Table 1 The coordinates and description of the borehole water sample points

\begin{tabular}{|c|c|c|c|}
\hline Sample points & Coordinates & Elevation & Description \\
\hline A & $\begin{array}{l}05^{\circ} 28^{\prime} 18.6^{\prime \prime} \mathrm{N} \\
00702^{\prime} 21.4 \mathrm{E}\end{array}$ & $74 \mathrm{~m}$ & Residential building within the reclaimed waste dumpsite along Akachi road \\
\hline B & $\begin{array}{l}05^{\circ} 27^{\prime} 57.0^{\prime \prime} \mathrm{N} \\
007^{\circ} 02^{\prime} 37.1^{\prime \prime} \mathrm{E}\end{array}$ & $77 \mathrm{~m}$ & A car wash beside a hotel within the reclaimed waste dumpsite along Akachi road \\
\hline $\mathrm{C}$ & $\begin{array}{l}05^{\circ} 28^{\prime} 0.62^{\prime \prime} \mathrm{N} \\
00702^{\prime} 36.4^{\prime \prime} \mathrm{E}\end{array}$ & $79 \mathrm{~m}$ & Shopping mall located within the reclaimed waste dumpsite \\
\hline $\mathrm{D}$ & $\begin{array}{l}05^{\circ} 28^{\prime} 02.2^{\prime \prime} \mathrm{N} \\
007^{\circ} 02^{\prime} 23.5^{\prime \prime} \mathrm{E}\end{array}$ & $78 \mathrm{~m}$ & A hotel complex located within the reclaimed waste dumpsite \\
\hline $\mathrm{E}$ & $\begin{array}{l}05028^{\prime} 21.8^{\prime \prime} \mathrm{N} \\
007^{\circ} 02^{\prime} 27.3^{\prime \prime} \mathrm{E}\end{array}$ & $67 \mathrm{~m}$ & A residential area that is very close to the reclaimed waste dumpsite \\
\hline Control (CL) & $\begin{array}{l}05028^{\prime} 57.3^{\prime \prime} \mathrm{N} \\
007^{\circ} 03^{\prime} 43.4^{\prime \prime} \mathrm{E}\end{array}$ & $58 \mathrm{~m}$ & $\begin{array}{l}\text { Sample collected from a residential area where there is no history of usage as a } \\
\text { waste dumpsite }\end{array}$ \\
\hline
\end{tabular}


Germany. Detergents and deionized water were used to wash the glassware and sample bottles. They were soaked overnight with a solution of $10 \% \mathrm{HNO}_{3}$ in a $1 \% \mathrm{HCl}$ solution, followed by rinsing with deionized water. Also, reagents used for the determination of anion concentrations with the Hanna Hi 83,200 Instrument were sourced from Hanna Instruments. The instrument (Agilent 240FS AA) used for the détermination of the concentrations of metallic elements in the samples has high sensitivity-typically $>0.9$ absorbance with a precision of $<0.5 \%$ RSD from ten-second integrations for $5 \mathrm{mg} / \mathrm{L} \mathrm{Cu}$ standard.

\section{Data analysis}

Data were subjected to mean, standard deviation, variance, and coefficient of variation, correlation and quantitative health risk analysis using Microsoft Excel 2010 and IBM SPSS version 20.0 .

\section{Quantitative health risk assessments}

Human exposure pathways to heavy metal contamination in water could be through direct ingestion and dermal absorption. The human exposure risk through the ingestion of the underground water samples was calculated using the USEPA risk assessment guidelines as shown in Eq. (1) (Li and Zhang 2010; Naveedullah et al. 2014; USEPA 1989).

$\operatorname{Exp}_{\text {ing }}=\frac{\mathrm{Cw} \times \mathrm{RI} \times \mathrm{FE} \times \mathrm{DE}}{\mathrm{Bw} \times \mathrm{AT}}$ in $\mathrm{mg} / \mathrm{kg} /$ day

where $\mathrm{Cw}=$ concentration of metal in water sample $(\mathrm{mg} /$ $\mathrm{kg}), \mathrm{RI}=$ rate of ingestion, for adult $=2.2 \mathrm{~L} /$ day and $1.8 \mathrm{~L} /$ day for children, $\mathrm{FE}=$ frequency of exposure $=365$ days $/$ year, $\mathrm{DE}=$ duration of exposure $=70$ years and 6 years for children, $\mathrm{Bw}=$ average body weight for adult $=70 \mathrm{~kg}$ and $15 \mathrm{~kg}$ for children, AT = average time $=365 \times 70$ days $/$ year for adults and 365 days/year $\times 6$ years for children (AsareDonkor et al. 2016; Li and Zhang 2010; Naveedulla et al. 2014).

\section{Hazard quotient}

The exposure risks due to the ingestion of metallic pollutants present in the underground water samples were estimated as the hazard quotient (HQ) with the help of Eq. (2).

$\mathrm{HQ}_{\text {ing }}=\frac{\operatorname{Exp}_{\text {ing }}}{\mathrm{RFD}}$

where $\mathrm{HQ}_{\text {non.car }}=$ hazard quotient (HQ) for non-carcinogenic risk, $\mathrm{Rfd}=$ Reference dose of the metal (Iqbal and Shah 2013; Li and Zhang 2010; USEPA 1989)

\section{Hazard index}

The risk due to ingestion of the borehole water contaminated by more than one metallic pollutants and sources were determined by the summation of individual HQ of the metallic pollutants as the hazard index (HI) using Eq. (3) (Ibe et al. 2019a). Hazard index values, above one ( $\mathrm{HI}>1$ ), are an indication of health risk which may result from intake of the water samples (Li and Zhang 2010; Naveedullah et al. 2014).

$$
\begin{aligned}
\mathrm{HI}= & \sum_{i=1}^{n} \mathrm{HQ}_{\text {ing(Al) }}+\mathrm{HQ}_{\mathrm{ing}(\mathrm{Cr})}+\mathrm{HQ}_{\mathrm{ing}(\mathrm{Cu})}+\mathrm{HQ}_{\mathrm{ing}(\mathrm{Fe})} \\
& +\mathrm{HQ}_{\mathrm{ing}(\mathrm{Mn})}+\mathrm{HQ}_{\mathrm{ing}(\mathrm{Zn})}
\end{aligned}
$$

where HI is a hazard index resulting from the ingestion of the underground water from the reclaimed waste dump site due to its use for drinking and domestic purposes.

\section{Chronic daily intake of metallic contaminants}

The health risk associated with the ingestion of heavy metal through the consumption of underground water in the study area was assessed using the chronic daily intake and hazard index parameter [Eq. (4)] (Boateng et al. 2015; Muhammad et al. 2011; Wu et al. 2009).

$\mathrm{CDI}=\frac{\mathrm{Cw} \times \mathrm{Di}}{\mathrm{Bw}}$

where $\mathrm{Cw}=$ concentration of the metallic element in water in $\mathrm{mg} / \mathrm{L}$, Di and Bw represent the average daily intake of water and body weight, respectively, average daily intake of water (2.2 L/day for adults; $1.8 \mathrm{~L} /$ day for children) and body weight (70 kg for adults; $15 \mathrm{~kg}$ for children), respectively (Asare-Donkor et al. 2016; Li and Zhang 2010; Naveedullah et al. 2014).

\section{Carcinogenic risks}

A carcinogenic risk explains the increased likelihood of developing cancer by individuals living in the area after some time due to their exposure to carcinogens through the consumption of the groundwater. The tolerable range of carcinogenic risks is within $1.0 \mathrm{E}-06$ to $1.0 \mathrm{E}-04$ (USEPA 2010). The Carcinogenic risks exposure by inhabitants of the reclaimed waste dump site was estimated according to Eq. (5) as described by Iqbal and Shah (2013) and Naveedullah et al. (2014).

$\mathrm{CR}=\frac{\operatorname{Exp}_{\text {ing }}}{\mathrm{SF}}$

where CR is the carcinogenic risk due to the ingestion of polluted water and SF is the carcinogenic slope factor, ingestion 
$(\mathrm{mg} / \mathrm{g} / \mathrm{day})^{-1}$. CR was estimated to show the lifetime carcinogenic risk of consuming contaminated water from the study area. The $S F$ value is $0.5 \mathrm{mg} / \mathrm{kg} /$ day for $\mathrm{Cr}$ (Boateng et al. 2019; Edokpayi et al. 2018; Naveedullah et al. 2014). The SF values for other metals were not available.

\section{Contamination assessment factor}

The level of metallic contamination was assessed as the contamination factor, which was estimated as the proportion of the individual metallic pollutants to its background values using Eq. (6).

$C_{f}=\frac{C_{\text {metal }}}{C_{\text {background }}}$

where $C_{f}$ represents contamination factor, $C_{\text {metal }}$ represents the concentration of heavy metal, and $C_{\text {background }}$ is the background value of the metal. The guidelines for safe drinking water were taken as background values (WHO 2004a).

\section{The pollution load index (PLI)}

To estimate the overall heavy metal pollution of the underground water in the study area, pollution load index (PLI) of the heavy metals studied was estimated according to Eq. (7) (Ibe et al. 2019a).

$\mathrm{PLI}=\sqrt[n]{C_{f 1}} \times C_{f 2} \times C_{f 3} \times \ldots \ldots C_{f n}$

where PLI $=$ Pollution load index,$n=$ number of investigated metallic elements,

\section{Water quality index (WQI)}

The water quality index was estimated with thirteen chemical properties of the underground water samples as presented in Table 2, using Eq. (8) (Chatterjee and Raziuddin 2002; Lele et al. 2018).

$\mathrm{WQI}=\frac{\sum_{i=1}^{n} W_{i} q_{i}}{\sum_{i=1}^{n} W_{i}}$

where WQI is the water quality index, $W_{i}$ indicates the unit weight, while $q$ is the quality rating. The WQI values were classified as; WQI $<50$ indicating excellent water quality, $50<\mathrm{WQI} \leq 100$ means good water quality, $100<\mathrm{WQI} \leq 200$ indicates poor water quality, $200<\mathrm{WQI} \leq 300$ implies very poor water quality, and WQI $>300$ indicates that the water is unsuitable for consumption (Ramakrishnaiah et al. 2009).

\section{Results and discussion}

\section{Physicochemical properties}

The results of the analyzed groundwater samples are presented in Table 2. Low-temperature values ranging from 5.82 to $7.25^{\circ} \mathrm{C}$ was observed in the water samples. The values are not unexpected since the groundwater samples were collected in the morning hours in July during the onset of the rainy season in the area. The recorded temperature values are within the WHO recommended values for safe drinking water. At higher temperatures, there is an increased respiration rate leading to the consumption of more oxygen as well as increased decomposition of organic materials (Nishizaki and Carrington 2014). Elevated groundwater temperature

Table 2 Physicochemical properties of the groundwater samples

\begin{tabular}{|c|c|c|c|c|c|c|c|c|c|c|c|}
\hline Parameter & A & B & $\mathrm{C}$ & $\mathrm{D}$ & $\mathrm{E}$ & CL & Mean & STD & Var & $\% \mathrm{CV}$ & WHO \\
\hline $\mathrm{pH}$ & 7.21 & 6.28 & 6.18 & 6.15 & 6.50 & 6.24 & 6.427 & 0.403 & 0.163 & 6.27 & $6.5-8.5$ \\
\hline $\mathrm{T}\left({ }^{\circ} \mathrm{C}\right)$ & 6.40 & 7.25 & 5.82 & 6.61 & 6.50 & 6.40 & 6.49 & 0.447 & 0.163 & 6.88 & 30 \\
\hline $\mathrm{EC}(\mu \mathrm{s} / \mathrm{cm})$ & 8.10 & 10.30 & 9.70 & 7. 30 & 13. 80 & 4.30 & 6.20 & 2.687 & 7.22 & 43.33 & 100 \\
\hline TDS (mg/L) & 55.00 & 15.00 & 45.00 & 15.00 & 40.00 & 12.00 & 30.33 & 18.57 & 344.67 & 61.20 & 250 \\
\hline $\mathrm{NO}_{3}^{-}(\mathrm{mg} / \mathrm{L})$ & 16.30 & 5.50 & 36.80 & 2.30 & 18.70 & 2.10 & 13.62 & 13.40 & 179.42 & 98.37 & 10 \\
\hline $\mathrm{PO}_{4}^{-3}(\mathrm{mg} / \mathrm{L})$ & 0.20 & 0.40 & 0.40 & 2.60 & 0.01 & 0.12 & 0.60 & 0.99 & 0.987 & 164.68 & 5 \\
\hline $\mathrm{SO}_{4}^{-2}(\mathrm{mg} / \mathrm{L})$ & $<0.001$ & $<0.001$ & $<0.001$ & $<0.001$ & $<0.001$ & $<0.001$ & 0.00 & 0.00 & 0.00 & 0.00 & 100 \\
\hline $\mathrm{Zn}(\mathrm{mg} / \mathrm{L})$ & 0.15 & 0.13 & 0.12 & 0.17 & 0.21 & 0.15 & 0.15 & 0.03 & 0.00 & 20.71 & 5.00 \\
\hline $\mathrm{Mn}(\mathrm{mg} / \mathrm{L})$ & 0.30 & 0.10 & 0.30 & 0.20 & 0.10 & 0.01 & 0.17 & 0.11 & 0.01 & 70.33 & 0.40 \\
\hline $\mathrm{Cr}(\mathrm{mg} / \mathrm{L})$ & 0.06 & 0.09 & 0.04 & 0.01 & 0.02 & 0.01 & 0.04 & 0.03 & 0.00 & 83.19 & 0.05 \\
\hline $\mathrm{Al}(\mathrm{mg} / \mathrm{L})$ & 0.25 & 0.08 & 0.15 & 0.26 & 0.18 & 0.04 & 0.16 & 0.09 & 0.00 & 55.48 & 0.20 \\
\hline $\mathrm{Fe}(\mathrm{mg} / \mathrm{L})$ & 0.03 & 0.02 & 0.01 & 0.02 & 0.01 & 0.01 & 0.02 & 0.01 & $6.67 \mathrm{E}-05$ & 48.98 & 0.30 \\
\hline $\mathrm{Cu}(\mathrm{mg} / \mathrm{L})$ & 0.40 & 0.01 & 0.02 & 0.02 & 0.001 & 0.01 & 0.08 & 0.16 & 0.03 & 206.37 & 2.00 \\
\hline
\end{tabular}

WHO World Health Organization standard for drinking water, $C L$ control, STD standard, Var variance, \%CV percentage coefficient of variation 
may be attributed to increased solar radiation (Ekwe et al. 2013). Change in the global climate resulting from increased temperatures could influence groundwater availability as a result of low rainfall as well as variation in seasonal rainfall, which may cause a serious decrease in the quantity of water available for aquifer recharge (Sun et al.2014). Some physical and chemical properties, as well as biological constituents of water, are also influenced by temperature. The observed low-temperature levels of the groundwater samples imply low decomposition of organic materials in the water which means decreased bacteria population (Ramana and Singh 2000).

The observed $\mathrm{pH}$ values of the water samples ranged from 6.15 to 7.21 with some of the $\mathrm{pH}$ values of the water samples been slightly lower than the WHO recommended $\mathrm{pH}$ levels for safe drinking water as shown in Table 2. Sample A has the highest $\mathrm{pH}$ value (7.21) indicating weak alkaline water samples while samples B, C, D, and CL with pH levels of $6.28,6.18,6.15$, and 6.24 respectively indicate water samples with low acidity. The low $\mathrm{pH}$ values recorded in most of the water samples may be attributed to anthropogenic acidification and the presence of autochthonous constituents in the reclaimed dumpsite. The susceptibility of most groundwater sources like boreholes in the area to acidification is believed to be associated with the shallow groundwater levels in the area which makes them easily accessible to contaminants (Anornu et al. 2012; Ejiogu et al. 2017; Ijeh and Onu 2013). Dependence of most groundwater sources on wetlands is another factor that may result in groundwater acidification. Wetlands containing oxidizeable sulphur compounds tend to severely acidify groundwater sources (Appleyard et al. 2004). Another major cause of groundwater acidification is due to the presence of sulphidic peaty sediments; this is more especially where groundwater systems depend on wetland supplies (Appleyard et al. 2004). Therefore, the observed low $\mathrm{pH}$ in most of the groundwater samples may be associated with the presence of waste deposits like used coal and other bituminous materials in the dumpsites (Obodo and Ibe 2017). The $\mathrm{pH}$ of the water to a great extent determines the solubility of most chemical components like metallic elements, as well as the availability of nutrients for biological activities in water (Rubiat et al., 2017). Acidosis which leads to peptic ulcer may result from the intake of water with a low pH level (Akubugwu and Duru 2001). Also, earlier reports have shown that the ingestion of water with low $\mathrm{pH}$ levels may cause unbalanced electrolyte levels and irregular heartbeats, which may result in coma (Duru et al. 2017a, b; Ibe et al. 2020a, b). Similar findings were reported in the study of borehole water from Uzoubi Umunna Orlu (Lele et al. 2018). Also, low $\mathrm{pH}$ levels were reported in groundwater resources of parts of Owerri Metropolis (Ibe et al. 2020a, b).

Electrical conductivity (EC) values recorded in the present study ranged from 4.30 to $13.80 \mu \mathrm{s} / \mathrm{cm}$. Elevated EC values were obtained in all the samples except sample D and the control. High EC values were observed for the entire samples collected within the reclaimed waste dumpsite. However, these high EC values are within the WHO acceptable EC limit. Higher EC values in groundwater sources within waste dumpsites indicate increased ionic concentrations which could be associated with the migration of leachates. Electrical conductivity is usually dependent on the number of dissolved materials (Corwin and Yemoto 2017). Electrical conductivity determines the quality and acceptability of water for domestic and industrial usage and could be greatly influenced by charged particles (Pradeep1998). Total dissolved solids (TDS) indicate the presence of dissolved inorganic salts and organic materials present in water solution, which tends to impair the taste of water (Rubiat et al. 2017). TDS levels of the water samples from the study area ranged from 12 to $55 \mathrm{mg} / \mathrm{L}$ and were within the WHO limit for drinking water quality. However, samples A, C, and D showed elevated TDS levels, which could be associated with the infiltration of leachates from the reclaimed waste dumpsite (Okiongbo and Akpofure 2012). Gastrointestinal problems could result from the intake of water with elevated TDS levels. TDS could also cause significant variation in water quality since the chemical constituents of groundwater are influenced by soil solubility and aquifer depth (Goeppert and Goldscheider 2001). Water with low salt content generally results when water flows through the poor soluble soils for short distances, whereas high salt content of groundwater usually results if aquifer recharge is accomplished by water flowing through soluble soil possibly due to the presence of carbonate rocks (De Giglio et al. 2015).

\section{Concentration of anions}

Observed phosphate values in the water samples were within the range of $0.01-2.60 \mathrm{mg} / \mathrm{L}$. The phosphate levels recorded in the samples were within the WHO permissible limit for safe drinking water. The higher phosphate levels recorded in sample D compared to other samples could be due to leachates from decomposed solid wastes in the reclaimed waste dumpsite, as well as runoff from the nearby farmlands as a result of the application of agrochemicals (Singh et al. 2012). The use of phosphate-based fertilizers for crop cultivation could increase the phosphate levels in groundwater sources (Elinge et al. 2011). This, therefore, is very possible since some part of this reclaimed waste dumpsite is used for cultivation of vegetables (Ibe et al. 2017). Other sources of phosphate in groundwater could be through the breakdown of minerals and rocks, accumulation of sediments, decay of dead or waste from wildlife, and animals (Singh et al. 2012). Though phosphate is needed in the body for proper functioning, however, a concentration above the tolerable limit could be deleterious and may result in osteoporosis 
and damage to the kidney (Calvo and Uribarri 2013). Phosphorous has been identified as a restrictive nutrient in water bodies, therefore, monitoring its level in water sources will help to control eutrophication and maintain suitable water quality (Holman et al. 2008).

The nitrate levels ranged from 2.10 to $36.80 \mathrm{mg} / \mathrm{L}$ with elevated nitrate levels recorded in samples A, C, and E above the WHO limit for safe drinking water. The observed high nitrate levels in the samples call for concern and need for these water samples to be treated before consumption. Elevated nitrate and $\mathrm{pH}$ levels were reported in groundwater quality studies of Densu Basin, Ghana (Tay and Kortatsi 2008). Also, a high nitrate level was reported in a study of water resources in Imo State (Ejiogu et al. 2017). Similar findings have been reported in a related study (Vincent et al. 2012). The observed elevated nitrate levels could be attributed to anthropogenic activities due to indiscriminate dumping of wastes such as agricultural wastes. Nitrate contamination of surface and groundwater sources may arise through many sources such as the use of inorganic and organic fertilizers in crop cultivation, release of organic waste and sewage into the surrounding environment as well as atmospheric depositions (Egereonu 2005; Egereonu and Ozuzu 2005; Ibe et al. 2016). Also, groundwater contamination by nitrate may be due to discharge of effluents from companies such as textile, metal processing, plywood, household cleaning, pharmaceutical, and plastic industries (Acharya and Ballav 2011; Lee et al. 2011; Singh et al. 2006). Elevated nitrate levels in the human body could interfere with the transport of oxygen by the red blood cells. Ingestion of water containing high nitrate concentrations by infants may result in difficulties in breathing due to reduced oxygen circulation, and methaemoglobinaemia which is also known as a blue baby syndrome (Follet and Follet 2008; Majumdar 2003).

Very low sulphate levels $(<0.001 \mathrm{mg} / \mathrm{L})$ were observed in all the water samples. The observed sulphate levels in the present study were comparable to earlier reports of borehole water assessment in Nekede Mechanic Village, Owerri (Duru et al. 2019). High sulphate concentrations in contaminated rivers and groundwater sources are the major sources of increased sulphur fluctuation levels in wetlands (Geurts et al. 2009). Though sulphates occur naturally in drinking water, anthropogenic factors could increase the concentrations in water bodies. Sulphates are also released into groundwater sources through the dissolution of sulphate bearing minerals in the soil (Bashir et al. 2012). The observed sulphate levels in the samples could be attributed to the shallow depth of the groundwater sources, which renders them vulnerable to contamination due to anthropogenic influence (Ejiogu et al. 2019; Ekeleme et al. 2015; Ijeh 2014a). There is presently no substantiated unpleasant health problem in humans and animals due to prolonged intake of sulphate contaminated water, though, infants show higher sensitivity to sulphate pollution. Some members of the population could be at higher risk from the laxative effects of sulphate contamination when there is a sudden change from the intake of water with low sulphate contents to the ingestion of water with high sulphate level (Abdulrafiu 2011).

\section{The concentration of metallic elements}

$\mathrm{Zn}$ concentrations in the water samples ranged from 0.12 to $0.21 \mathrm{mg} / \mathrm{L}$. These values were generally low and within the accepted WHO standard for safe drinking water. Zinc is an important component of numerous proteins in flora and fauna. The antioxidant properties of $\mathrm{Zn}$ and its ability to protect against rapid skin and muscle aging in humans are well documented (Wu et al. 2009). However, the concentration of $\mathrm{Zn}$ in drinking water above a certain threshold could be toxic. Anthropogenically, $\mathrm{Zn}$ could be introduced into the environment through its industrial usage as well as its presence in some liquid manure, composted materials, and agrochemicals such as animal feeds, fertilizers, and pesticides (Nitasha and Sanjiv 2015). The presence of Zn in groundwater samples may be due to leachates from metallic wastes or $\mathrm{Zn}$ containing materials disposed of in the waste dumpsite before it was reclaimed. Another major source of $\mathrm{Zn}$ ion in the environment is through erosion of roofing materials such as zinc, aluminium and galvanized metal roofing sheets, as well bulk atmospheric deposits (Ibe et al. 2016; Ibe and Ibe 2016; Chang et al. 2004; Gromaire-Mertz et al. 1999). Elevated concentrations of dissolved $\mathrm{Zn}$ ion in drinking water especially tap water may result from oxidation and leaching of the metal from water supply fittings and pipes (Duru et al. 2017b). Ingestion of water containing high levels of Zn may cause fever, stomach cramps, vomiting, and diarrhea as well as an increase in $\mathrm{Cu}$ deficiency (Elinder 1986). The concentration of $\mathrm{Zn}$ obtained in the present study is comparable to the values reported by Ogoko (2017) and Iheme et al. (2018).

Mn levels observed in the water samples ranged from 0.10 to $0.30 \mathrm{mg} / \mathrm{L}$ and are therefore slightly less than the WHO standard for safe drinking water. Average Mn concentration of $0.15,0.09$, and $0.1 \mathrm{mg} / \mathrm{L}$ for groundwater, reservoirs, and distribution networks, respectively, were reported in Qom city, Iran (Fahiminia et al. 2015). The major source of Mn in groundwater is from rainfall, dissolution of Mn minerals in nearby rocks, and leaching /percolation of Mn through the soil (Ichu et al. 2018). Acidic groundwater sources tend to show elevated Mn levels in reduced form (Manganese Fact Sheet 2013). It has been reported that other sources (metal alloys, batteries, glass, and ceramic materials) of $\mathrm{Mn}$ in wastes dumpsite could contribute to Mn concentrations in the soil as well as in groundwater sources (Kabata-Pendias 2011). Though $\mathrm{Mn}$ is a biologically essential element, intake of Mn through groundwater above the WHO permissible 
limit of $0.40 \mathrm{mg} / \mathrm{L}$ may result in neurological injury (WHO 2011; Manganese Fact sheet 2013). Manganese is considered to possess low toxicity through the oral route due to the limitations posed by homeostasis to gastrointestinal absorption. There is evidence of increasing neurotoxicity through the oral route mainly in infants. Little children have a more sensitive nervous system, unlike adults, in addition to the fact that they have less developed homeostasis. Though low levels of $\mathrm{Mn}$ is contained in breast milk, minimal levels of Mn may be found in infant food formulations, which tends to increase $\mathrm{Mn}$ concentrations in infants. In addition, since infant foods are usually in powdered form, the food is dissolved in water which naturally contains $\mathrm{Mn}$, thereby significantly increasing infant's exposure to $\mathrm{Mn}$ concentrations (Ljung and Vahter 2007). A documented report suggested that Mn toxicity may result in adverse health consequences on the brain and respiratory system, as well as the possibility of Parkinson's disease and bronchitis. The report further indicated that myasthenia, insomnia, and imbecility, including headache, are some of the symptoms of Mn poisoning (Kiani et al. 2013).

The observed value of $\mathrm{Al}$ for the samples ranged from 0.04 to $0.26 \mathrm{mg} / \mathrm{L}$. Elevated concentration of $\mathrm{Al}$ was recorded in most of the water samples. Sample A $(0.25 \mathrm{mg} / \mathrm{L})$ and $\mathrm{D}(0.26 \mathrm{mg} / \mathrm{L})$ revealed a higher concentration of $\mathrm{Al}$ above WHO permissible limit $(0.20 \mathrm{mg} / \mathrm{L})$, while the $\mathrm{Al}$ concentration in sample $\mathrm{C}(0.15 \mathrm{mg} / \mathrm{L})$ and $\mathrm{E}$ $(0.18 \mathrm{mg} / \mathrm{L})$ were slightly below the WHO limit for drinking water. Lower concentrations $(0.11 \mathrm{mg} / \mathrm{L}$ and 0.12$)$ of $\mathrm{Al}$ were reported in Sungai Lembing and Bukit Ubi, Kuantan, Malaysia respectively (Dzulfakar et al. 2011). A filtrable concentration of $\mathrm{Al}$ was reported in buffalo pound water treatment plant (BPWTP) (Srinivasan and Viraraghavan 2002). The presence of high $\mathrm{Al}$ concentrations in the present study could be attributed to the several used aluminium materials dumped in the dumpsite over the years in addition to other sources, as $\mathrm{Al}$ is widespread in nature, and the element is found in water, air, plants as well as food materials (Narin et al. 2004). The Earth's surface is covered by about $8 \%$ of $\mathrm{Al}$ and its compounds are considered among the most abundant elements and naturally, it is found in bauxite, silicates, and cryolite (Dzulfakar et al. 2011; Krewski et al. 2007). Al has several uses such as in product packaging, drug, water treatment, food, and in many consumer goods, mainly due to its chemical and physical properties (Health Canada 2008). Anthropogenic activities such as disposal of $\mathrm{Al}$ metal scraps, and used $\mathrm{Al}$ foils may result in subsequent leaching and infiltration of $\mathrm{Al}$ and its compounds into the underlying aquiferous units. This could be true since food wastes like beans pudding, roasted fish, pizza, can drinks, etc., are usually disposed of with the $\mathrm{Al}$ packaging materials in the waste dumpsites (Habian 2011; Centre for Food Safety 2013). Al is an essential element, but can be toxic when excess concentration is ingested into the body. Intake of an excess concentration of $\mathrm{Al}$ has neurotoxicity potential and has been associated with Alzheimer's disease (Habian 2011; Centre for Food Safety 2013). Therefore, the consumption of water with elevated Al levels could increase the risk of Alzheimer's disease in the area. A study of correlation of $\mathrm{Al}$ levels in drinking water and Alzheimer's disease revealed that concentrations greater than $0.1 \mathrm{mg} / \mathrm{L}$ were linked to increased risk of Alzheimer's disease and dementia (Rondeau et al. 2000).

Elevated $\mathrm{Cr}$ levels were observed in some of the water samples analyzed in the study area. Concentrations of $\mathrm{Cr}$ in the samples were in the range of $<0.001-0.06 \mathrm{mg} / \mathrm{L}$. The concentration of $\mathrm{Cr}$ in sample A was above the WHO stipulated value for safe drinking water. High $\mathrm{Cr}(0.282 \mathrm{mg} / \mathrm{L})$ concentration was reported in Obite Rivers State Nigeria (Nnaji et al. 2016). Cr is introduced through the combustion of oil and coal, crude oil with Ferro-chromate refractory constituents, drilling of oil wells, chromium steel, plating, tanneries, pigment oxidants, and catalysts. Other anthropogenic activities such as fertilizer application and sewage disposal could also introduce $\mathrm{Cr}$ into the environment (Ghani 2011). Also, Cr could be introduced into the environment through copper alloys, rubber, paper, paints, and magnetic tapes (Martin and Griswold 2009). Cr is considered one of the most abundant elements in the earth's crust (Mohanty and Kumar 2013). It exists in different oxidation numbers (Rodriguez et al. 2007), with trivalent $\mathrm{Cr}^{+3}$ and hexavalent $\mathrm{Cr}^{+6}$ forms having greater toxicity on man and animals (Mohanty and Kumar 2013). According to the International Agency for the Research on Cancer, $\mathrm{Cr}$ is regarded as group one human carcinogen due to its high toxicity (Jaishankar et al. 2014). Acute $\mathrm{Cr}$ toxicity results in the onset of diffuse hyperplasia of the small intestine, which is the most responsive end point and precursor of malignant growth in humans (Health Canada 2015). Also, it has been reported that chronic exposure to $\mathrm{Cr}$ reduces fertility in males (Hong et al. 2001). This implies that the ingestion of Cr contaminated water could put the health of consumers at risk of cancer-related illness and infertility.

The concentrations of $\mathrm{Fe}$ observed in the study ranged from 0.01 to $0.03 \mathrm{mg} / \mathrm{L}$, which were within the WHO permissible limit $(0.03 \mathrm{mg} / \mathrm{L})$ for safe drinking water. The levels of Fe obtained in this study were less than the lowest concentration $(0.957 \mathrm{mg} / \mathrm{L})$ recorded in the Kumasi landfill site (Boateng et al. 2019). Fe levels recorded in the present study were comparable to values reported by Duru et al. (2019) and Ejiogu et al. (2017). Iron is an essential element needed for the development and the continued existence of living organisms; it plays a crucial role in the metabolism of living organisms (Ibe et al. 2019b; Valko et al. 2005). Naturally, the metal occurs in groundwater due to weathering of iron-containing soils like laterites. 
Leachates from waste dumps and landfills, drainages from acid-mine, sewage, and industrial effluents are some of the anthropogenic sources of iron which could contribute to iron concentration in groundwater sources (Water Stewardship Information Series 2007). Little children are very sensitive to iron toxicity because of their exposure to products with elevated Fe concentration (Albretsen, 2006). Overdose of iron intake results in gastrointestinal problems, increased risk of cancer, and could be lethal (Sane et al. 2018).

$\mathrm{Cu}$ concentrations ranged from 0.01 to $0.40 \mathrm{mg} / \mathrm{L}$ in the water samples. Though low concentrations of $\mathrm{Cu}$ were obtained in all the water samples as well as the control samples, a slightly higher concentration of $\mathrm{Cu}$ was recorded in sample A $(0.04 \mathrm{mg} / \mathrm{L})$, sample C $(0.02 \mathrm{mg} / \mathrm{L})$, and $0.02 \mathrm{mg} / \mathrm{L}$ also for sample $\mathrm{D}$. The concentrations of $\mathrm{Cu}$ recorded in the present study were within the WHO permissible limit $(2.00 \mathrm{mg} / \mathrm{L})$ for safe drinking water. The concentration of $\mathrm{Cu}$ in the present study is similar to the values obtained in a previous study as reported in Corlu, Turkey (Ongena et al. 2008). As a trace mineral element, $\mathrm{Cu}$ exists naturally in plants where it participates in most decisive vital mechanisms. $\mathrm{Cu}$ is considered essential in the regulation of some biological processes and the maintenance of vascular and skeletal integrity (Ibe et al. 2019c). Prolonged intake of $\mathrm{Cu}$ contaminated water could result in haematuria, gastrointestinal bleeding, intravascular haemolysis, hepatocellular toxicity, oliguria, and acute renal failure (Agarwal et al. 1993; Ashish et al. 2013; Hefnawy and Elkhaiat 2015; WHO 2004b).

\section{Correlation analysis}

The level of association of the pollutants was established using the Pearson product-moment correlation analysis. The result of the correlation analysis is presented in Table 3 . The result revealed that strong positive correlations were observed between $\mathrm{pH}$ and EC $(r=0.950, p>0.05)$. Also, $\mathrm{pH}$ showed a significant positive association with $\mathrm{Cu}(r=0.935$, $p>0.05)$, indicating that there is $\mathrm{pH}$ dependency of metal concentration in the groundwater samples, which implies that elevated concentration of metals in the water samples may be due to high solubility of metals at low pH (Enyoh et al. 2018). Similarly, EC had a very strong positive correlation with $\mathrm{Cu}(r=0.999, p>0.01)$. It was further observed that moderate positive correlation existed between $\mathrm{Zn}$ and $\mathrm{Cr}(r=0.636, p>0.05)$ and between $\mathrm{Mn}$ and $\mathrm{Cu}(r=0.590$, $p>0.05)$, while $\mathrm{Cu}$ and $\mathrm{Fe}(r=0.809, p>0.01)$ showed a high positive correlation. The observed correlations between the metallic pollutants suggested possible similar sources of origin. Therefore, it could be deduced that the observed concentrations of the metals are associated with metallic scraps disposed of in the reclaimed waste dump site.

\section{Human health risk}

Table 4 is the result of the calculated exposure dose (mg/ $\mathrm{kg} /$ day), through the ingestion of underground water from the reclaimed waste dump site. Since most of the inhabitants of the study area ingest and use the underground water

Table 3 Correlation matrix for the physiochemical parameter in water

\begin{tabular}{|c|c|c|c|c|c|c|c|c|c|c|c|c|c|}
\hline & \multicolumn{13}{|c|}{ Correlations } \\
\hline & $\overline{\mathrm{pH}}$ & Temp & $\mathrm{EC}$ & TDS & $\mathrm{NO}_{3}^{-}$ & $\mathrm{PO}_{4}^{-3}$ & $\mathrm{SO}_{4}^{-2}$ & $\mathrm{Zn}$ & $\mathrm{Mn}$ & $\mathrm{Cr}$ & $\mathrm{Al}$ & $\mathrm{Fe}$ & $\mathrm{Cu}$ \\
\hline $\mathrm{pH}$ & 1 & -0.053 & $0.950^{*}$ & 0.697 & 0.027 & -0.458 & 0 & 0.129 & 0.347 & 0.256 & 0.414 & 0.677 & $0.935^{*}$ \\
\hline Temp & & 1 & -0.121 & -0.697 & -0.857 & 0.118 & 0 & 0.115 & -0.749 & 0.471 & -0.331 & 0.353 & -0.139 \\
\hline $\mathrm{EC}$ & & & 1 & 0.646 & 0.016 & -0.275 & 0 & -0.094 & 0.559 & 0.279 & 0.496 & 0.802 & $0.999 * *$ \\
\hline TDS & & & & 1 & 0.721 & -0.626 & 0 & 0.012 & 0.619 & -0.034 & 0.281 & 0.066 & 0.640 \\
\hline $\mathrm{NO}_{3}^{-}$ & & & & & 1 & -0.539 & 0 & -0.269 & 0.532 & -0.092 & -0.160 & -0.512 & 0.021 \\
\hline $\mathrm{PO}_{4}^{-3}$ & & & & & & 1 & 0 & 0.072 & 0.045 & -0.503 & 0.492 & 0.144 & -0.247 \\
\hline $\mathrm{SO}_{4}^{-2}$ & & & & & & & 1 & 0 & 0 & 0 & 0 & 0 & 0 \\
\hline $\mathrm{Zn}$ & & & & & & & & 1 & -0.489 & $0.636^{*}$ & 0.412 & -0.200 & -0.123 \\
\hline $\mathrm{Mn}$ & & & & & & & & & 1 & -0.078 & 0.471 & 0.299 & $0.590 *$ \\
\hline $\mathrm{Cr}$ & & & & & & & & & & 1 & -0.637 & 0.410 & 0.273 \\
\hline $\mathrm{Al}$ & & & & & & & & & & & 1 & 0.418 & 0.508 \\
\hline $\mathrm{Fe}$ & & & & & & & & & & & 0.418 & 1 & 0.809 \\
\hline $\mathrm{Cu}$ & & & & & & & & & & & 0.508 & $0.809 * *$ & 1 \\
\hline
\end{tabular}

*Correlation is significant at the 0.05 level (2-tailed)

**Correlation is significant at the 0.01 level (2-tailed) 
Table 4 Exposure dose ( $\mathrm{mg} / \mathrm{kg} / \mathrm{day})$ due to the intake of the groundwater

\begin{tabular}{|c|c|c|c|c|c|c|c|c|c|c|c|c|}
\hline \multirow[t]{2}{*}{ Parameter } & \multicolumn{2}{|l|}{ A } & \multicolumn{2}{|l|}{ B } & \multicolumn{2}{|l|}{$\mathrm{C}$} & \multicolumn{2}{|l|}{$\mathrm{D}$} & \multicolumn{2}{|l|}{$\mathrm{E}$} & \multicolumn{2}{|l|}{$\mathrm{C} 1$} \\
\hline & Ad & $\mathrm{Ch}$ & Ad & $\mathrm{Ch}$ & Ad & $\mathrm{Ch}$ & Ad & $\mathrm{Ch}$ & Ad & $\mathrm{Ch}$ & Ad & $\mathrm{Ch}$ \\
\hline $\mathrm{Zn}(\mathrm{mg} / \mathrm{L})$ & 0.047 & 0.018 & 0.041 & 0.0156 & 0.038 & 0.0144 & 0.0535 & 0.0204 & 0.0661 & 0.0252 & 0.047 & 0.018 \\
\hline $\operatorname{Mn}(\mathrm{mg} / \mathrm{L})$ & 0.094 & 0.036 & 0.0315 & 0.012 & 0.094 & 0.036 & 0.063 & 0.024 & 0.0315 & 0.012 & 0.0031 & 0.0012 \\
\hline $\mathrm{Cr}(\mathrm{mg} / \mathrm{L})$ & 0.019 & 0.0072 & 0.028 & 0.011 & 0.0126 & 0.0048 & 0.0031 & 0.0012 & 0.0063 & 0.0024 & 0.0031 & 0.0012 \\
\hline $\mathrm{Al}(\mathrm{mg} / \mathrm{L})$ & 0.079 & 0.03 & 0.025 & 0.0096 & 0.047 & 0.018 & 0.082 & 0.0312 & 0.057 & 0.0216 & 0.0126 & 0.0048 \\
\hline $\mathrm{Fe}(\mathrm{mg} / \mathrm{L})$ & 0.0094 & 0.0036 & 0.0063 & 0.0024 & 0.0031 & 0.0012 & 0.0063 & 0.0024 & 0.0031 & 0.0012 & 0.0031 & 0.0012 \\
\hline $\mathrm{Cu}(\mathrm{mg} / \mathrm{L})$ & 0.126 & 0.048 & 0.0031 & 0.0012 & 0.0063 & 0.0024 & 0.0063 & 0.0024 & 0.00031 & 0.00012 & 0.0031 & 0.0012 \\
\hline
\end{tabular}

Key: Ad Adult, $C h$ Children

for drinking and other domestic activities, the health risk posed by the investigated metallic pollutants on children and adults through ingestion was estimated using Eq. (1)-(5). It was observed that the exposure dose due to ingestion of the groundwater for all the metallic pollutants was $<1$ for adults and children. This suggests less health risk to the inhabitants of the reclaimed waste dumpsite.

The estimated HQ for direct ingestion of the water for both adults and children varied for the metallic pollutants (Table 5). The HQ for $\mathrm{Zn}$ was below unity indicating little adverse health effect due to consumption of the groundwater. $\mathrm{HQ}$ for $\mathrm{Fe}$ and $\mathrm{Cu}$ showed similar trend except for $\mathrm{Fe}$ concentration in adults for sample $\mathrm{A}$ and $\mathrm{Cu}$ for both adults and children in sample B. Elevated HQ values $>1$ were observed for both adults and children in all the samples for $\mathrm{Cr}$, suggesting tendency of adverse health effect. HI (Table 5) for the investigated water samples showed values greater than unity for both adults and children. This suggests that the prolonged consumption of water samples from these groundwater sources could cause serious health damages, if adequate measures were not taken to remediate the reclaimed waste dumpsite, especially due to $\mathrm{Cr}$ contamination. The health risk assessment indicates that the presence of $\mathrm{Cr}$ in the water samples resulted in serious pollution of the groundwater sources within the reclaimed waste dumpsite. Exposure to elevated levels of $\mathrm{Cr}$ could result in serious health challenges (Hong et al. 2001). Experimental studies have shown that compounds of $\mathrm{Cr}$ could lead to deoxyribonucleic acid (DNA) damage, which results in the creation of DNA adducts, altered DNA repetition, and DNA's inability to be accurately transcribed (O'Brien et al. 2001; Matsumoto et al. 2006).

The result of the chronic daily intake risk assessment (CDI) for the metals in the groundwater samples through ingestion pathways is shown in Table 6. CDI like other health risk assessment tools such as hazard quotient and hazard index values of $<1$ are usually suggestive of minimal health risk (Wu et al. 2009). The observed overall CDI values were all less than unity. This indicates less significant health risk through the ingestion of the groundwater (Asare-Donkor et al. 2016; Zhao et al. 2009). However, the prolonged consumption of the groundwater may cause major damages to human health due to the tendency of these metallic pollutants to bioaccumulate. The CDI values for children varied between $1.2 \mathrm{E}-3$ and $4.8 \mathrm{E}-2$, while that of adults ranged from $3.1 \mathrm{E}-4$ to $47.1 \mathrm{E}-3$. The highest CDI value for children was observed in sample A, while sample E revealed the highest CDI value for adults. The CDI indices for the metallic contaminants were found to follow the decreasing order of $\mathrm{Al}>\mathrm{Mn}>\mathrm{Zn}>\mathrm{Cu}>\mathrm{Cr}>\mathrm{Fe}$, suggesting that $\mathrm{Al}$ had the highest CDI value, followed by $\mathrm{Mn}$, while Fe showed the least CDI value. This is evident in the observed levels of Al in some samples from the study area which were above WHO Standard limits for drinking water.

Table 5 Hazard quotient and Hazard index

\begin{tabular}{|c|c|c|c|c|c|c|c|c|c|c|c|c|c|}
\hline \multirow[t]{3}{*}{ Metals } & \multicolumn{12}{|c|}{ Sample points } & \multirow[t]{3}{*}{ RfD } \\
\hline & \multicolumn{2}{|l|}{$\mathrm{A}$} & \multicolumn{2}{|l|}{ B } & \multicolumn{2}{|l|}{$\mathrm{C}$} & \multicolumn{2}{|l|}{$\mathrm{D}$} & \multicolumn{2}{|l|}{$\mathrm{E}$} & \multicolumn{2}{|l|}{$\mathrm{Cl}$} & \\
\hline & Ad & $\mathrm{Ch}$ & Ad & $\mathrm{Ch}$ & Ad & $\mathrm{Ch}$ & Ad & $\mathrm{Ch}$ & Ad & $\mathrm{Ch}$ & Ad & $\mathrm{Ch}$ & \\
\hline $\mathrm{Zn}$ & 0.157 & 0.06 & 0.137 & 0.052 & 0.127 & 0.048 & 0.173 & 0.068 & 0.220 & 0.084 & 0.157 & 0.06 & 0.3 \\
\hline $\mathrm{Cr}$ & 63.33 & 24 & 93.33 & 36.67 & 42.00 & 16.00 & 10.33 & 4.00 & 21.00 & 8.00 & 10.33 & 4.00 & 0.0003 \\
\hline $\mathrm{Fe}$ & 1.343 & 0.514 & 0.90 & 0.343 & 0.443 & 0.171 & 0.90 & 0.343 & 0.443 & 0.171 & 0.443 & 0.171 & 0.007 \\
\hline $\mathrm{Cu}$ & 3.15 & 1.20 & 0.0775 & 0.03 & 0.1575 & 0.06 & 0.1575 & 0.06 & 0.00775 & 0.003 & 0.0775 & 0.03 & 0.04 \\
\hline $\mathrm{HI}$ & 67.98 & 25.774 & 94.4445 & 37.095 & 42.728 & 16.279 & 11.561 & 4.471 & 21.671 & 8.258 & 11.001 & 4.261 & \\
\hline
\end{tabular}


The Carcinogenic risks (CRs) value for $\mathrm{Cr}$ is shown in Table 7. The carcinogenic risk of $\mathrm{Cr}$ for the groundwater samples was estimated for both children and adults, but it could not be established for $\mathrm{Al}, \mathrm{Cu}, \mathrm{Fe}, \mathrm{Mn}$, and $\mathrm{Zn}$ due to the absence of their carcinogenic slope factor values in the literature. Carcinogenic risk values between $10^{-6}$ and $10^{-4}$ for an individual suggests potential risk. Therefore, the estimated result shows that the levels of $\mathrm{Cr}$ in the investigated borehole water samples for both adults and children could pose a serious health risk. Adequate control measures should be taken to protect human health and consumers of the groundwater from the study area. Elevated CR values have been reported in a related study of groundwater samples in South Africa (Edokpayi et al. 2018). Geological processes such as weathering and the use of fertilizers and pesticides in agriculture must have contributed to the elevated $\mathrm{Cr}$ levels in the groundwater in the study area (He et al. 2004; Ndimele and Kumolu-Johnson 2012). Studies have revealed the tendency of elevated $\mathrm{Cr}$ (III) levels in the cell to damage DNA in humans (Kart et al. 2016; Novotnik et al. 2016). The groundwater in the study area should be properly treated before consumption to make the water safe for the inhabitants of the area.

\section{Pollution assessment}

The contamination factor and pollution load index of the heavy metals investigated are presented in Table 8 . The contamination factor values recorded in the present study were categorized according to a previous study (Nweke and Ukpai 2016). Contamination factor values recorded in the present study ranged from 0.0005 to 1.3 , with the least value recorded in sample $\mathrm{E}$, while the highest value was observed in sample D. It was observed that the high contamination factor value in sample $\mathrm{D}$ was due to elevated $\mathrm{Al}$ levels in the groundwater samples. The contamination factor values for the metallic contaminants, therefore, followed the decreasing order of $\mathrm{Cr}>\mathrm{Al}>\mathrm{Mn}>\mathrm{Fe}>\mathrm{Cu}>\mathrm{Zn}$, indicating that $\mathrm{Zn}$ had the least contamination factor among the studied elements. Generally, a low contamination factor was exhibited by all

Table 6 The Chronic Daily Intake of Metal contaminants in the study area

\begin{tabular}{|c|c|c|c|c|c|c|c|c|c|c|c|c|}
\hline \multirow[t]{3}{*}{ Metal } & \multicolumn{12}{|c|}{ Sample Points } \\
\hline & \multicolumn{2}{|l|}{ A } & \multicolumn{2}{|l|}{ B } & \multicolumn{2}{|l|}{$\mathrm{C}$} & \multicolumn{2}{|l|}{$\mathrm{D}$} & \multicolumn{2}{|l|}{ E } & \multicolumn{2}{|l|}{$\mathrm{C} 1$} \\
\hline & Ad & $\mathrm{Ch}$ & Ad & $\mathrm{Ch}$ & Ad & $\mathrm{Ch}$ & Ad & $\mathrm{Ch}$ & Ad & $\mathrm{Ch}$ & Ad & $\mathrm{Ch}$ \\
\hline $\mathrm{Zn}$ & 0.00471 & 0.0156 & 0.00377 & 0.0156 & 0.00377 & 0.0144 & 0.00534 & 0.0204 & 0.0066 & 0.0252 & 0.00471 & 0.018 \\
\hline Mn & 0.00943 & 0.0360 & 0.0031 & 0.012 & 0.0094 & 0.036 & 0.0063 & 0.024 & 0.0031 & 0.012 & 0.00031 & 0.0012 \\
\hline $\mathrm{Cr}$ & 0.0019 & 0.0072 & 0.0028 & 0.011 & 0.0013 & 0.0048 & 0.00031 & 0.0012 & 0.0006 & 0.0024 & 0.00031 & 0.0012 \\
\hline $\mathrm{Al}$ & 0.0079 & 0.0300 & 0.0025 & 0.0096 & 0.0047 & 0.018 & 0.0082 & 0.0312 & 0.0251 & 0.0216 & 0.0013 & 0.0048 \\
\hline $\mathrm{Fe}$ & 0.00094 & 0.0036 & 0.00063 & 0.0024 & 0.00031 & 0.0012 & 0.00063 & 0.0024 & 0.00031 & 0.0012 & 0.00031 & 0.0012 \\
\hline $\mathrm{Cu}$ & 0.0126 & 0.048 & 0.00031 & 0.0012 & 0.00063 & 0.0024 & 0.00063 & 0.0024 & 0.000031 & 0.00012 & 0.00031 & 0.0012 \\
\hline
\end{tabular}

Table 7 Carcinogenic risks due to $\mathrm{Cr}$ contamination

\begin{tabular}{|c|c|c|c|c|c|c|c|c|c|c|c|c|}
\hline \multirow[t]{2}{*}{ Metal } & \multicolumn{2}{|l|}{ A } & \multicolumn{2}{|l|}{ B } & \multicolumn{2}{|l|}{$\mathrm{C}$} & \multicolumn{2}{|l|}{$\mathrm{D}$} & \multicolumn{2}{|l|}{$\mathrm{E}$} & \multicolumn{2}{|l|}{$\mathrm{C} 1$} \\
\hline & Ad & $\mathrm{Ch}$ & $\mathrm{Ad}$ & $\mathrm{Ch}$ & $\mathrm{Ad}$ & $\mathrm{Ch}$ & Ad & $\mathrm{Ch}$ & Ad & $\mathrm{Ch}$ & $\mathrm{Ad}$ & $\mathrm{Ch}$ \\
\hline $\mathrm{Cr}(\mathrm{mg} / \mathrm{L})$ & 0.038 & 0.0144 & 0.056 & 0.022 & 0.0252 & 0.0024 & 0.0062 & 0.0024 & 0.0126 & 0.0048 & 0.0062 & 0.0024 \\
\hline
\end{tabular}

Table 8 Contamination factor and pollution load index of borehole water sample

\begin{tabular}{lllllll}
\hline Parameter & \multicolumn{7}{l}{ Contamination factor } & & & \\
\cline { 2 - 6 } & $\mathrm{A}$ & $\mathrm{B}$ & $\mathrm{C}$ & $\mathrm{D}$ & $\mathrm{E}$ & $\mathrm{C} 1$ \\
\hline $\mathrm{Zn}$ & 0.03 & 0.026 & 0.024 & 0.034 & 0.042 & 0.03 \\
$\mathrm{Mn}$ & 0.75 & 0.25 & 0.75 & 0.5 & 0.25 & 0.025 \\
$\mathrm{Cr}$ & 1.20 & 1.80 & 0.80 & 0.20 & 0.40 & 0.20 \\
$\mathrm{Al}$ & 1.25 & 0.40 & 0.75 & 1.3 & 0.9 & 0.20 \\
$\mathrm{Fe}$ & 0.10 & 0.067 & 0.03 & 0.067 & 0.03 & 0.03 \\
$\mathrm{Cu}$ & 0.20 & 0.005 & 0.01 & 0.01 & 0.0005 & 0.005 \\
$\mathrm{PLI}=$ & 0.296 & 0.108 & 1.00 & 0.12 & 0.062 & 0.041 \\
\hline
\end{tabular}


metals for the individual sampling sites except for $\mathrm{Cr}$ (1.20) in sample A and $\mathrm{Al}$ (1.3) in sample D. Control site (C1) was observed to generally have low contamination factor. Though a low pollution index was observed for all samples, sample $\mathrm{C}$ has a pollution load index of unity. The PLI followed the decreasing order of $\mathrm{C}>\mathrm{A}>\mathrm{D}>\mathrm{C}>\mathrm{E}>\mathrm{C} 1$. Chromium exposure over an extended period could cause serious health damages affecting the kidney, liver, circulatory, and nervous tissue (Njar et al. 2012). A similar observation indicating an elevated concentration of $\mathrm{Cr}$ in fifty-two (52) borehole water samples from twelve Local Governments Areas in Nasarawa State, Nigeria has been reported (Tukura et al. 2014). The observed elevated contamination factor for $\mathrm{Cr}$ and $\mathrm{Al}$ could, therefore, be attributed to anthropogenic inputs and geological sources (Arukwe et al. 2012).

Levels of metal contamination factor in the groundwater samples are presented in Fig. 3. Comparing the contamination factor of the control water sample with sample A-E revealed considerably high contamination of individual

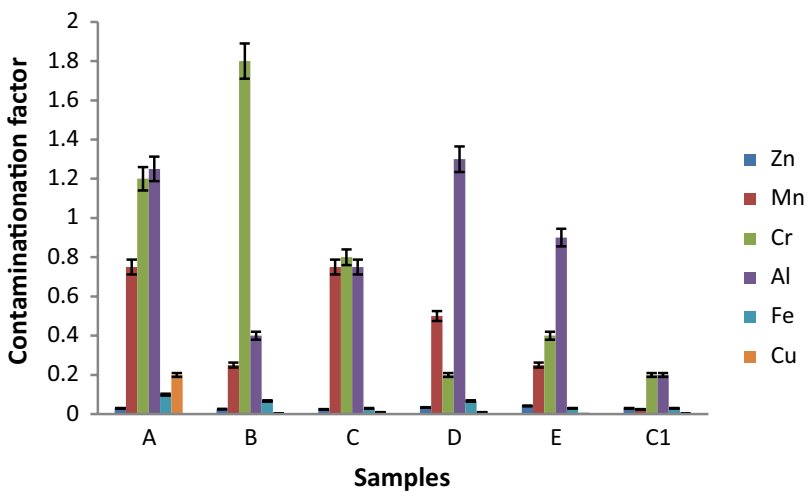

Fig. 3 Contamination factor of individual metals in borehole water samples heavy metals. Al and $\mathrm{Cr}$ were found to be more pronounced in Fig. 3, in terms of high pollution load index. The observed elevated contamination factor and pollution load index for $\mathrm{Al}$ and $\mathrm{Cr}$ suggested that the studied reclaimed waste dumpsite received enormous waste materials containing $\mathrm{Al}$ and $\mathrm{Cr}$ compounds. Based on deductions from Fig. 3, the contamination factor of the metallic contaminants is in the order $\mathrm{Cr}>\mathrm{Al}>\mathrm{Mn}>\mathrm{Cu}>\mathrm{Fe}>\mathrm{Cu}$ $>\mathrm{Zn}$, with $\mathrm{Cr}$ showing elevated PLI value.

\section{Water quality index}

The water quality index (WQI) of the groundwater samples was estimated according to Eq. (7). The WQI values of the present study were classified according to Chatterjee and Raziuddin (2002). Table 9 shows the water quality index of the groundwater samples from the reclaimed waste dump site $(\mathrm{Ci})$ and the control groundwater sample (CL). The WQI of $\mathrm{Ci}$ is an indication that the groundwater samples need to undergo further purification before consumption. The observed WQI of the study location was due to elevated levels of $\mathrm{Al}$ and $\mathrm{Cr}$ in some samples which call for serious concern. A previous toxicological study indicated that $\mathrm{Al}$ could pose a significant risk to humans and animals as well as plants as it could result in numerous diseases (Barabasz et al. 2002). Cr and its compounds are known for their toxicity in humans at elevated levels and are considered as carcinogens (Jaishankar et al. 2014). Borehole water studies in Orji, Owerri North in Imo State revealed that the WQI was of poor quality due to anthropogenic activities in the area (Duru et al. 2017a, b; Enyoh et al. 2018). Similar findings were observed by Abdul et al. (2010), while WQI values above 101 were reported for the Inyishi River (Ibe et al. 2019a).
Table 9 Water quality index of borehole water samples

\begin{tabular}{llllllll}
\hline Parameter & Mean $(\mathrm{Ci})$ & $\mathrm{CL}$ & $W_{i}$ & $\mathrm{q}(\mathrm{Ci})$ & $\mathrm{q}(\mathrm{CL})$ & $\mathrm{W} \mathrm{q}(\mathrm{Ci})$ & $\mathrm{W} \mathrm{q}(\mathrm{CL})$ \\
\hline $\mathrm{pH}$ & 6.464 & 6.24 & $3.9 \mathrm{E}-3$ & -53.6 & -76 & -0.209 & -0.2964 \\
$\mathrm{~T}\left({ }^{\circ} \mathrm{C}\right)$ & 6.508 & 6.40 & $1.0 \mathrm{E}-3$ & 21.69 & 21.33 & 0.0217 & 0.0213 \\
$\mathrm{EC}(\mu \mathrm{s} / \mathrm{cm})$ & 8.10 & 4.30 & $3.1 \mathrm{E}-4$ & 8.1 & 4.30 & $2.51 \mathrm{E}-3$ & $1.33 \mathrm{E}-3$ \\
$\mathrm{TDS}(\mathrm{mg} / \mathrm{L})$ & 34 & 12.00 & $1.24 \mathrm{E}-4$ & 13.6 & 4.8 & $1.69 \mathrm{E}-3$ & $6.0 \mathrm{E}-4$ \\
$\mathrm{NO}_{3}{ }^{-}(\mathrm{mg} / \mathrm{L})$ & 15.92 & 2.10 & $3.1 \mathrm{E}-3$ & 159.2 & 21 & 0.494 & 0.0074 \\
$\mathrm{PO}_{4}^{-3}(\mathrm{mg} / \mathrm{L})$ & 0.722 & 0.12 & $6.2 \mathrm{E}-3$ & 14.44 & 2.4 & 0.0895 & 0.0149 \\
$\mathrm{SO}_{4}{ }^{-2}(\mathrm{mg} / \mathrm{L})$ & 0.001 & 0.001 & $3.1 \mathrm{E}-4$ & 0.001 & 0.001 & $3.1 \mathrm{E}-7$ & $3.1 \mathrm{E}-7$ \\
$\mathrm{Zn}(\mathrm{mg} / \mathrm{L})$ & 0.156 & 0.15 & $6.2 \mathrm{E}-3$ & 3.12 & 3 & 0.0193 & 0.0186 \\
$\mathrm{Mn}(\mathrm{mg} / \mathrm{L})$ & 0.2 & 0.01 & 0.0775 & 50 & 2.50 & 3.875 & 0.1938 \\
$\mathrm{Cr}(\mathrm{mg} / \mathrm{L})$ & 0.044 & 0.01 & 0.62 & 88 & 20 & 54.56 & 12.4 \\
$\mathrm{Al}(\mathrm{mg} / \mathrm{L})$ & 0.184 & 0.04 & 0.155 & 92 & 20 & 14.26 & 3.1 \\
$\mathrm{Fe}(\mathrm{mg} / \mathrm{L})$ & 0.018 & 0.01 & 0.1033 & 6 & 3.33 & 0.6198 & 0.344 \\
$\mathrm{Cu}(\mathrm{mg} / \mathrm{L})$ & 0.0902 & 0.01 & 0.0155 & 4.51 & 0.5 & 0.070 & 0.0078 \\
& & & $\sum W_{i}=0.992$ & & & WQI $=73.804$ & WQI $=15.469$ \\
\hline
\end{tabular}




\section{Conclusion and recommendation}

The groundwater samples from the reclaimed waste dump site were examined using several risks and pollution evaluation models to reveal the water quality and its suitability for consumption. It was observed that groundwater samples $\mathrm{A}$ and $\mathrm{C}$ were mainly contaminated by $\mathrm{NO}_{3}^{-}$, while samples $\mathrm{A}$ and $\mathrm{B}$ were polluted due to elevated $\mathrm{Cr}$ concentration. Al levels in samples A and D were above the WHO tolerable value for safe drinking water. The significant positive correlations between $\mathrm{pH}, \mathrm{EC}$, and $\mathrm{Cu}$ are indications of $\mathrm{pH}$ dependency of $\mathrm{EC}$ and $\mathrm{Cu}$. The observed correlations between the metallic pollutants suggested similar sources of origin of these heavy metals and therefore may be associated with metallic scraps disposed in the waste dump site before reclamation. Though the exposure dose for both adult and children were $<1$, elevated HQ values $>1$ were observed for both adults and children in some samples, while HI values $>1$ for both adult and children were also recorded. CDI risk assessment revealed values $<1$, but carcinogenic risk values greater than $10^{-6}$ and $10^{-4}$ were observed for the samples due to $\mathrm{Cr}$, suggesting potential health risk for children and adults. Low $\mathrm{C}_{f}$ and PLI were observed for the entire samples except for sample $\mathrm{C}$ with a pollution load index of unity with the PLI following the decreasing order of $\mathrm{C}^{>} \mathrm{A}^{\text {> }}$ $D^{>} C^{>} E^{>} C 1$. It was observed that the WQI of groundwater from the reclaimed dumpsite could pose serious health risk due to elevated levels of $\mathrm{Al}$ and $\mathrm{Cr}$ recorded in the samples. Therefore, there is a serious need to treat water from the reclaimed dump site before consumption especially due to $\mathrm{Al}, \mathrm{Cr}$, and $\mathrm{NO}_{3}^{-}$pollution. The above observations revealed that prolonged consumption of groundwater from this reclaimed waste dump site may cause serious health challenges. It is, therefore, recommended that adequate measures should be taken by Government Agencies to remediate the reclaimed waste dumpsite, in order to avert possible health risk which may arise due to prolong intake of groundwater sources from the area.

Acknowledgments The authors wish to acknowledge the support of the Staff of Chemistry Research Laboratory, Imo State University, Owerri, for their technical support. We appreciate Martins Ashabelem and Franklin Ogwurumba for their participation during the fieldwork. The authors are also thankful to Engr. Clement Johnson of Laboratory Services and Environmental Research Department/UNIDO RAC for Pollution Monitoring and Assessment, Ministry of Environment and Petroleum, Imo State, Nigeria, for permission to carry out the research in the reclaimed dumpsite.

Author contributions Project conceptualization, investigation, methodology, and the first draft of the manuscript [Francis Chizoruo Ibe], the final draft of the manuscript and literature searches [Francis Chizoruo Ibe, Opara Alexander Iheanyichukw, Collins Emeka Amaobi, assisted by Bridget Onyekachi Ibe]. The final manuscript was read and approved by all the authors.
Funding No funding or grant was received for this study.

\section{Compliance with ethical standards}

Conflict of interest The authors declare that they have no conflict of interest.

Open Access This article is licensed under a Creative Commons Attribution 4.0 International License, which permits use, sharing, adaptation, distribution and reproduction in any medium or format, as long as you give appropriate credit to the original author(s) and the source, provide a link to the Creative Commons licence, and indicate if changes were made. The images or other third party material in this article are included in the article's Creative Commons licence, unless indicated otherwise in a credit line to the material. If material is not included in the article's Creative Commons licence and your intended use is not permitted by statutory regulation or exceeds the permitted use, you will need to obtain permission directly from the copyright holder. To view a copy of this licence, visit http://creativecommons.org/licenses/by/4.0/.

\section{References}

Abarikwu S, Iserhienrhien B, Badejo T (2013) Rutin-and selenium attenuated cadmium-induced testicular pathophysiology in rats. Hum Exp Toxicol 32:395-406

Abdul HM, Jawad A, Haider SA, Bahram KM (2010) Application of water quality index for assessment of Dokan Lake ecosystem, Kurdistan region, Iraq. J Water Resour Prot 2:792-798

Abdulrafiu OM (2011) Quality assessment of groundwater in the vicinity of dumpsites in Ifo and Lagos, Southwestern Nigeria. Adv Appl Sci Res 2(1):289-298

Abdus-Salam N, Ibrahim MS, Fatoyinbo FT (2011) Dumpsites in Lokoja, Nigeria: a silent pollution zone for underground water. Waste Manag Bioresour Technol 1:21-30

Acharya S, Ballav A (2011) Filler recovery from intermediate byproduct during single superphosphate production in a completely closed system. J Indu Res Technol 1(1):78-82

Adewuyi GO, Opasina MA (2010) Physicochemical and heavy metals assessments of leachates from aperin abandoned dumpsite in Ibadan City, Nigeria. E-J Chem 7(4):1278-1283

Agarwal SK, Tiwari SC, Dash SC (1993) Spectrum of poisoning requiring hemodialysis in a tertiary care hospital in India. Int $\mathbf{J}$ Artif Organs 16(1):20-22

Akinsanola AA, Ogunjobi KO (2014) Analysis of rainfall and temperature variability over Nigeria. Glob J Hum-Soc Sci: B Geogr, Geo-Sci, Environ Disaster Manag 14(3):1-19 (Version 1.0)

Akubugwu EI, Duru MKC (2001) Biochemical implication of the consumption of water from Otamiri River, Owerri, Imo State, Nigeria. JETEAS 2(6):934-937

Albretsen J (2006) The toxicity of iron, an essential element. Toxicology brief, managing common poisonings in companion animals. Veterinary medicine, February 2006, 82-90. https://pdfs. semanticscholar.org/a00f/9e8bdadc818110e65329a3449e8977 83854e.pdf?_ga=2.14531895.1634593549.1589786926-63787 464.1577684419. Accessed 29 Aug 2019

Amadi AN, Olasehinde PI, Okosun EA, Okoye NO, Okunlola IA, Alkali YB, Dan-Hassan MA (2012) A comparative study on the impact of Avu and ihie dumpsites on soil quality in Southeastern Nigeria. Am J Chem 2(1):17-23

Anornu GK, Kabo-bah AT, Anim-Gyampo M (2012) Evaluation of groundwater vulnerability in the Densu River Basin of Ghana. Am J Hum Ecol 1(3):79-86

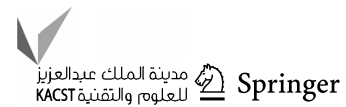


Appleyard S, Wong S, Willis-Jones B, Angeloni J, Watkins R (2004) Groundwater acidification caused by urban development in Pert, Western Austria: source, distribution, and implications for management. Aust J Soil Res 42:579-585

Arukwe A, Eggen T, Möder M (2012) Solid waste deposits as a significant source of contaminants of emerging concern to the aquatic and terrestrial environments-a developing country case study from Owerri, Nigeria. Sci Total Environ 438(1):94-102

Asare-Donkor NK, Boadu TA, Adimado AA (2016) Evaluation of groundwater and surface water quality and human risk assessment for trace metals in human settlements around the Bosomtwe Crater Lake in Ghana. Springer Plus 5(1812):1-19

Ashish B, Neeti K, Himanshu K (2013) Copper toxicity: a comprehensive study Res. J Recent Sci 2:558-567

Barabasz W, Albinska D, Jaskowska M, Lipiec J (2002) Ecotoxicology of aluminium. Pol J Environ Stud 11(3):199-203

Bashir MT, Ali S, Bashir A (2012) Health effects from exposure to sulphates and chlorides in drinking water pak. J Med Health Sci 6(3):644-652

Boateng TK, Opoku F, Acquaah SO, Akoto O (2015) Pollution evaluation, sources, and risk assessment of heavy metals in hand-dug wells from Ejisu-Juaben Municipality. Ghana Environ Syst Res $4(18): 1-12$

Boateng TK, Opoku F, Akoto O (2019) Heavy metal contamination assessment of groundwater quality: a case study of Oti landfill site, Kumasi. Appl Water Sci 9(33):1-15

Bellebaum J (2005) Between the Herring Gull Larus argentatus and the Bulldozer: black-headed Gull Larus ridibundus feeding sites on a refuse dump. Ornis Fennica 82:166-171

Bukar LI, Hati SS, Dimari GA, Tijjani M (2012) Study of vertical migration of heavy metals in dumpsites soil. ARPN J Sci Technol 2(2):50-55

Calvo MS, Uribarri J (2013) Public health impact of dietary phosphorus excess on bone and cardiovascular health in the general population. Am J Clin Nutr 98(1):6-15

Centre for Food Safety (2013) Risk assessment section May 2013. https://www.cfs.gov.hk/english/programme/programme_rafs/ files/Risk_in_Brief_Aluminium_in_food_e.pdf. Accessed 20 Aug 2019

Chang M, McBroom MW, Beasley RS (2004) Roofing as a source of non-point water pollution. J Environ Man 73(4):307-315

Chatterjee C, Raziuddin M (2002) Determination of water quality index (WQI) of a degraded river in Asansol industrial area (West Bengal). Nat Environ Poll Tech 1(2):181-189

Chineke TC, Idinoba ME, Ajayi OC (2011) Seasonal evapotranspiration signatures under a changing landscape and ecosystem management in Nigeria: implications for agriculture and food security. Am J Sci Ind Res 2(2):191-204

Chukwu KE (2015) Water supply management policy in Nigeria: challenges in the wetland area of Niger Delta. Eur Sci J 11:303-323

Corwin DL, Yemoto K (2017) Salinity: electrical conductivity and total dissolved solids. Methods of soil analysis, vol 2. Soil Science Society of America, USA, pp 1-16

David OM, Oluyege AO (2014) Effect of open refuse dumpsite on the quality of underground water used for domestic purposes in Ado-Ekiti, Nigeria - a public health awareness study. J Environ Ecol 5(2):1-9

De Giglio O, Quaranta A, Barbuti G, Napoli C, Caggiano G, Montagna MT (2015) Factors influencing groundwater quality: towards an integrated management approach. Ann Ig 2:52-57

Duru CE, Okoro IP, Enyoh CE (2017a) Quality assessment of borehole water within Orji mechanic village using pollution and contamination models. Int J Chem Mat Environ Res 4(3):123-130

Duru CE, Duru IA, Ibe FC, Enedoh MC (2017b) Profiling of $\mathrm{Zn}^{2+}$ ion sorption in modeled aqueous solutions by different parts of Maize Biomass. IOSR J Appl Chem 10(3):70-75 (Ver.1)
Duru CE, Enedoh MC, Duru IA (2019) Physicochemical assessment of borehole water in a reclaimed section of Nekede mechanic village, Imo State, Nigeria. Chem Afr. https://doi.org/10.1007/ s42250-019-00077-8

Dzulfakar MA, Shaharuddin MS, Muhaimin AA, Syazwan AI (2011) Risk assessment of aluminium in drinking water between two residential areas. Water 3:882-893

Edokpayi JN, Enitan AM, Mutileni N, Odiyo JO (2018) Evaluation of water quality and human risk assessment due to heavy metals in groundwater around Muledane area of Vhembe District, Limpopo Province, South Africa. Chem Central J 12(2):1-16

Egereonu UU (2005) A study on the groundwater pollution by nitrates in the environment, Aba, Nigeria. J Chem Soc Nigeria 30(2):211-218

Egereonu UU, Ozuzu CIU (2005) Physiochemical analysis of the River Niger at Onisha Bank. Nigeria J Chem Soc Nigeria 30(2):197-203

Ejiogu BC, Opara AI, Nwofor OK, Nwosu EI (2017) Geochemical and bacteriological analyses of water resources prone to contamination from solid waste dumpsites in Imo State, Southeastern Nigeria. J Environ Sci Technol 10:25-343

Ejiogu BC, Opara AI, Nwosu EI, Nwofor OK, Onyema JC, Chinaka JC (2019) Estimates of aquifer geo-hydraulic and vulnerability characteristics of Imo State and environs, Southeastern Nigeria, using electrical conductivity data. Environ Monit Assess 191:238. https://doi.org/10.1007/s10661-019-7335-1

Ekeleme AC, Ibearugbulem OH, Ugwuegbulam JC (2015) Groundwater quality in parts of Owerri Imo State in South-Eastern Nigeria. Inter J Civil Eng, Const Chem Pred Estate Manag $3(1): 62-72$

Ekeleme AC, Okoro BC, Ibearugbulem OH, Nwadike EC, Egedigwe AC (2014) Assessment of groundwater quality in selected areas in Imo State in Southeastern Nigeria. J Environ Earth Sci 4(9):52-58

Ekwe MC, Joshua JK, Igwe JE (2013) Estimation of daily global solar irradiation at Owerri, Imo State Nigeria from hours of sunshine, minimum and maximum temperature, and relative humidity. Int J Appl Res Stud 2(3):1-14

Elinder CG (1986) Zinc. In: Friberg L, Nordberg GF, Vouk VB (eds) Handbook on the toxicology of metals, 2nd edn. Elsevier, Amsterdam, pp 664-676

Elinge CM, Itodo AU, Peni IJ, Birnin-Yauri UA, Mbongo AN (2011) Assessment of heavy metals concentrations in bore-hole waters in Aliero community of Kebbi State. Adv Appl Sci Res 2(4):279-282

Enyoh CE, Verla AW, Verla EN, Ibe FC, Amaobi CE (2019) Airborne microplastics: a review study on a method for analysis, occurrence, movement, and risks. Environ Monit Assess 191(668):1-17

Enyoh CE, Verla AW, Egejuru NJ (2018) pH Variations and Chemometric Assessment of Borehole Water in Orji, Owerri Imo State. Nigeria J Environ Anal Chem 5(2):1-9

Fahiminia M, Jafari Mansoorian H, Ansari M, Saifour Mofrad A, Majidi G, Ansari Tadi R, Majd Tabatabai MS (2015) Evaluation of trends for iron and manganese concentrations in wells, reservoirs, and water distribution networks, Qom city. Iran Environ Health Eng Manag J 2(2):67-72

Farombi E, Akintunde J, Nzute N, Adedara I, Arojojoye O (2012) Municipal landfill leachate induces hepatotoxicity and oxidative stress in rats. Toxicol Ind Health 28:532-541

Follett JR, Follett RF (2008) Relationship of environmental nitrogen metabolism to human health publications from USDA-ARS/UNL Faculty. 260. https://digitalcommons.unl.edu/usdaarsfacpub/260. Accessed 25 Sept 2019

FRN (2000) the Federal Republic of Nigeria, water supply \& sanitation interim strategy note November $2000 \mathrm{http}: / /$ siteresources.world 
bank.org/NIGERIAEXTN/Resources/wss1100.pdf. Accessed 26 Sept 2019

FRN (2007) (Federal Republic of Nigeria), Official Gazette, Legal Notice on publication of the details of the Breakdown of the National and State Provisional total, 2006 Census. In: Federal Republic of Nigeria Official Gazette, Government Notice No. 21, Lagos, 15 May 2007, Vol. 94, pp 1-26

Geurts JJM, Sarneel JM, Willers BJC, Roelofs JGM, Verhoeven JTA, Lamers LPM (2009) Interacting effects of sulphate pollution, sulphide toxicity and eutrophication on vegetation development in fens: a mesocosm experiment. Environ Pollut 157:2072-2081

Ghani A (2011) Effect of chromium toxicity on growth, chlorophyll and some mineral nutrients of Brassica juncea L. Egypt Acad J Biol Sci 2(1):9-15

Goeppert N, Goldscheider N (2001) Transport and variability of fecal bacteria carbonate conglomerate aquifers. Ground Water 49(1):77-84

Gromaire-Mertz MC, Garnaud GA, Chebbo G (1999) Characterization of Urban runoff pollution in Paris. Wat Sci Tech 39(2):1-8

Habian A (2011) Hazards of aluminum packaging. https://digitalcom mons.calpoly.edu/cgi/viewcontent.cgi $?$ article $=1080 \&$ conte $\mathrm{xt}=$ grcsp. Accessed 24 Aug, 2019

He Z, Zhang M, Calvert D, Stoffella P, Yang X, Yu S (2004) Transport of heavy metals in surface runoff from vegetable and citrus fields. Soil Sci Soc Am J 68(5):1662-1669

Hefnawy A, Elkhaiat H (2015) The importance of copper and the effects of its deficiency and toxicity in animal health. Int J Livestock Res 5(12):1-20

Health Canada (2015) Chromium drinking water. http://www.healt hycanadians.gc.ca/health-system-systeme-sante/consultations/ chromium-chrome/alt/chromium-chrome-eng.pdf. Accessed 24 Aug 2019

Health Canada (2008) Aluminium http://www.hc-sc.gc.ca/ewh-semt/ pubs/water-eau/aluminum/referencesbibliographiques-eng.php. Accessed 18 May 2020

Holman IP, Whelan MJ, Howden NJK, Bellamy PH, Willby NJ, RivasCasad M, McConvey P (2008) Phosphorus in groundwater-an overlooked contributor to eutrophication. Hydrol Process 22:5121-5127

Hong L, Qiongyu C, Shien L, Wu Y, Linghong L, Xianglin S, Liying W, Vince C, Val V, Erik E, Chen C (2001) Effect of Cr(VI) exposure on sperm quality, human, and animal studies. Ann Occupa hyg 45(7):505-511

Ichu BC, Opara AI, Ibe FC (2018) Contamination Assessment of Heavy Metals in Road Dust of the University of Nigeria, Enugu Campus, Southeastern Nigeria. Aust J Bas Appl Sci 12(12):1-8

Ibe FC, Ibe BO (2016) Roof runoff water as a source of pollution: a case study of some selected roofs in Orlu metropolis, Imo State, Nigeria. Int Lett Nat Sci 50:53-61

Ibe FC, Ibe BO, Enyoh CE (2019a) Trace metal, FTIR, and phytochemical analysis of Viscum the album leaves harvested from Pentaclethra macrophylla. World News Nat Sci 25:61-71

Ibe FC, Ibe BO, Nzenwa PO, Enedoh MC (2019b) Phytochemical, FTIR and elemental studies of African Mistletoe (Viscum album) leaves on Colanitida from South-Eastern Nigeria. World Sci News 132:84-97

Ibe FC, Isiuku BO, Enyoh CE (2017) Trace metals analysis of soil and edible plant leaves from the abandoned municipal waste dumpsite in Owerri, Imo State, Nigeria. World News Nat Sci 13:27-42

Ibe FC, Enyoh CE, Opara AI, Ibe BO (2020a) Evaluation of pollution status of groundwater resources of parts of Owerri metropolis and environs, Southeastern Nigeria, using health risk and contamination models. Int J Energ Water Res. https://doi. org/10.1007/s42108-020-00071-8
Ibe FC, Njoku PC, Alinnor JI, Opara AI (2016) Evaluation of ambient air quality in parts of Imo State, Nigeria. Res J Chem Sci $6(1): 41-52$

Ibe FC, Opara AI, Ibe BO, Amaobi CE (2019c) Application of assessment models for pollution and health risk from effluent discharge into a tropical stream: a case study of Inyishi River. Southeast Nigeria Environ Monit Assess 191(753):1-15

Ibe FC, Opara AI, Duru CE, Isiuku BO, Enedoh MC (2020b) Statistical analysis of atmospheric pollutant concentrations in parts of Imo State. Southeast Nigeria Sci Afr 7(e00237):1-27

Ibe FC, Opara AI, Ibe BO, Adindu BC, Ichu BC (2018) Environmental and Health implications of trace metal concentrations in street dust around some electronic repair workshops in Owerri, Southeastern Nigeria. Environ Monit Assess 190(696):1-14

Ibe KM (1999) Migration of contaminants into groundwater at a landfill site: A case study of the Avu landfill site Owerri, SE. Nigeria Int J Environ Health Res 9:55-66

Iheme KO, Akudinobi EB, Oyeleke TA, Ibrahim KO, Abubakar HO, Usman AO (2018) An evaluation of groundwater and surface water resources in Orlu and environs, South Eastern Nigeria. J Bas Phys Res 8(2):31-38

Ijeh I, Onu N (2012) Appraisal of the aquifer hydraulic characteristics from electrical sounding data in Imo River Basin, South Eastern Nigeria: The case of Imo Shale and Ameki Formations. J Environ Earth Sci 2(30):61-76

Ijeh IB, Onu NN (2013) Assessment of pollution levels of groundwater in parts of Imo River Basin, South Eastern Nigeria. Int J Water Resour Environ Eng 5:194-202

Ijeh IB (2014a) Groundwater quality assessment of parts of Owerri, Southeastern Nigeria. Journal of Environmental Science, Toxicology, and Food Technology 8(2):63-70 (Ver. II)

Ijeh IB (2014b) Appraisal of groundwater quality in parts of the Benin formation in Imo River Basin, Southeastern Nigeria. Pac J Sci Technol 15(1):433-442

Ikem A, Osibanjo O, Sridhar MKC, Sobande A (2002) Evaluation of groundwater quality characteristics near two waste sites in Ibadan and Lagos Nigeria. Water Air Soil Pollut 140:307-333

Iqbal J, Shah MH (2013) Health risk assessment of metals in surface water from freshwater source lakes Pakistan. Hum Ecol Risk Assess Int J 19(6):1530-1543

Ishaku HT, Rafee Majid M, Ajayi AP, Haruna A (2011) Water supply dilemma in Nigerian rural communities: looking towards the sky for an answer. J Water Resour Prot 3:598-606

Jaishankar M, Tseten T, Anbalagan N, Mathew BB, Beeregowda KN (2014) Toxicity, mechanism and health effects of some heavy metals. Interdiscip Toxicol 7(2):60-72

Kabata-Pendias A (2011) Trace elements in soils and plants, 4th edn. CRC Press, Boca Raton, p 12

Kart A, Koc E, Dalginli KY, Gulmez C, Sertcelik M, Atakisi O (2016) The therapeutic role of glutathione in oxidative stress and oxidative DNA damage caused by hexavalent chromium. Biol Trace Elem Res 174(2):387-391

Kiani H, Shahmohamadi S, Hadi M (2013) Study of breakthrough curves for column of bed to remove manganese from aqueous solution by the windy sand of sistan plain. J Environ 39(1):21-30

Krewski D, Yokel RA, Nieboer E, Borchelt D, Cohen J, Harry J, Kacew S, Lindsay J, Mahfouz AM, Rondeau V (2007) Human health risk assessment for aluminium, aluminium oxide, and aluminium hydroxide. J Toxicol Environ Health Part B 10:1-269

Kumar CP (2012) Climate change and its impact on groundwater resources. Int J Eng Sci 1(5):43-60

Lee J, Alkarkhi AFM, Kadir MOA, Ahmad A (2011) Electrocoagulation of chemical, mechanical polishing (CMP) wastewater treatment with alluminium electrodes: parameter optimizing using response surface methodology (RSM). J Ind Res Technol $1(1): 24-31$

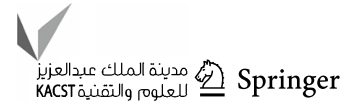


Lele KC, Verla AW, Amaobi CE, Ajero AI, Enyoh CE, Verla EN (2018) Health risks of consuming untreated borehole water from Uzoubi Umunna Orlu, Imo State Nigeria. J Environ Anal Chem 5(4):1-7

Li SY, Zhang QF (2010) Spatial characterization of dissolved trace elements and heavy metals in the upper Han River (China) using multivariate statistical techniques. J Hazard Mater 176(1-3):579

Ljung K, Vahter M (2007) Time to Re-evaluate the guideline value for manganese in drinking water. Environ Health Perspect 115:1533-1538

Longe EO, Omole DO, Adewumi IK, Ogbiye AS (2010) Water resources use abuse and regulations in Nigeria. J Sustain Dev Afr 12(2):35-44

Majumdar D (2003) The blue baby syndrome: Nitrate poisoning in humans. Resonance 8(10):20-30

Manganese Fact Sheet 6 (2013) International Manganese Institute, https://studyres.com/doc/20637806/manganese-in-groundwate r-research-and-potential-risks. Accessed 25 Sept 2019

Martin S, Griswold W (2009) Human health effects of heavy metals. Environ Sci Technol Br Citiz 15:1-6

Matsumoto ST, Mantovani MS, Malaguttii MIA, Dias AL, Fonseca IC, Marin- Morales MA (2006) Genotoxicity and mutagenicity of water contaminated with tannery effluents, as evaluated by the micronucleus test and comet assay using the fish Oreochromis niloticus and chromosome aberrations in onion root-tips. Genet Mol Biol 29(1): 148-158

Mohanty M, Kumar PH (2013) Effect of ionic and chelate assisted hexavalent chromium on mung bean seedlings (Vigna Radiata 1. Wilczek. Var k-851) during seedling growth. JSPB 9(2):232-241

Mor S, Ravindra K, Dahiya RP, Chandra A (2006) Leachate characterization and assessment of groundwater pollution near municipal solid waste dumpsite site. Environ Monit Assess 118(1-3):435-456

Muhammad S, Shah MT, Khan S (2011) Health risk assessment of heavy metals and their source apportionment in drinking water of Kohistan region, northern Pakistan. Microchem J 98:334-343

Muze NE, Opara AI, Ibe FC, Njoku OC (2020) Assessment of the geoenvironmental effects of activities of auto-mechanic workshops at Alaoji Aba and Elekahia Port Harcourt, Niger Delta, Nigeria. Environ Anal Health Toxicol 35(2):1-12

Narin I, Tuzen M, Soylak M (2004) Aluminium determination in environmental samples by graphite furnace atomic absorption spectrometry after solid-phase extraction on Amberlite XAD-1180/ pyrocatechol violet chelating resin. Talanta 63:411-418

Naveedullah MZH, Yu C, Shen H, Duan D, Shen C, Lou L, Chen Y (2014) Concentration and human health risk assessment of selected heavy metals in surface water of the Siling Reservoir watershed in Zhejiang Province, China. Pol J Environ Stud 23:801-811

NBS (2011) National Bureau of Statistics, National annual abstract of statistics 2011.The Federal Republic of Nigeria. http://istma t.info/files/uploads/53129/annual_abstract_of_statistics_2011. pdf. Accessed 29 July 2019

Ndimele PE, Kumolu-Johnson CA (2012) some aspects of the physico-chemistry and heavy metal content of water, sediment, and Cynothrissa mento (Regan, 1917) from Badagry Creek, Lagos, Nigeria. Trends Appl Sci Res 7:724-736

Nishizaki MT, Carrington E (2014) The effect of water temperature and flow on respiration in barnacles: patterns of mass transfer versus kinetic limitation. J Exp Biol 217:2101-2109

Nitasha K, Sanjiv T (2015) Influences of natural and anthropogenic factors on surface and groundwater quality in rural and urban areas. Front Life Sci 8(1):23-39

Njar GN, Iwara AI, Offiong RA, Deekor TD (2012) Assessment of the heavy metal status of boreholes in Calabar South Local Government Area, Cross River State. Nigeria Ethiop J Environ Stud Manag 5(1):86-91
Njoku P, Ibe FC, Alinnor J, Opara A (2016) Seasonal variability of carbon monoxide $(\mathrm{CO})$ in the ambient environment of Imo State, Nigeria. Int Lett Nat Sci 53:40-52

Nnaji AO, Idam JO, Njoku RE (2016) Assessment of variations in the concentration of heavy metals in groundwater within oilproducing communities of Rivers State. Nigeria J Pub Health Environ Pollut 1(1):001-013

Novotnik B, Ščančar J, Milačič R, Filipič M, Žegura B (2016) Cytotoxic and genotoxic potential of $\mathrm{Cr}(\mathrm{VI}), \mathrm{Cr}(\mathrm{III})$-nitrate and $\mathrm{Cr}(\mathrm{III})-\mathrm{EDTA}$ complex in human hepatoma (HepG2) cells. Chemosphere 154:124-131

Nweke MO, Ukpai SN (2016) Use of enrichment, ecological risk, and contamination factors with geo-accumulation indexes to evaluate heavy metal contents in the soils around Ameka Mining Area, South of Abakaliki, Nigeria. J Geogr, Environ Earth Sci Int 5(4):1-13

Obasi IA, Nnachi EE, Igwe OE, Obasi NP (2015) Evaluation of pollution status of heavy metals in the groundwater system around open dumpsites in Abakaliki urban, Southeastern Nigeria. Afr J Environ Sci Technol 9(7):600-609

Obasi NA, Obasi SE, Aloh GO, Nnachi EO (2017) Health risk assessment of selected dumpsites in the Amata-Akpoha community using cultivated edible plants. Res J Environ Toxi 11:62-71

Obeta MC (2017) Patterns and problems of domestic water supply to rural communities in Enugu State, Nigeria. J Agric Ext Rural Dev 9(8):172-184

Obodo GA, Ibe FC (2017) Industrial raw materials resource inventory, 2nd edn. Supreme Publishers, Owerri, pp 99-102

O'Brien T, Xu J, Patierno SR (2001) Effects of glutathione on chromium-induced DNA crosslinking and DNA polymerase arrest. Molecular mechanisms of metal toxicity and carcinogenesis. Springer, USA, pp 173-182

Ogoko EC (2017) Physicochemical properties and heavy metal concentration of groundwater in Owerri Metropolis, Nigeria. Curr J Appl Sci Technol 23(1):1-10

Okere KJ, Abu GO, Ndukwu B (2018) Estimation and characterization of municipal solid waste in Nekede landfill, Owerri metropolis, Nigeria. Int J Eng Appl Sci 5(3):93-100

Okiongbo KS, Akpofure E (2012) Determination of aquifer properties and groundwater vulnerability mapping using the geoelectric method in Yenagoa City and its environs in Bayelsa State, South-South Nigeria. J Water Resour Prot 4:354-362

Okoro UK, Chen W, Chineke TC, Nwofor OK (2014) Comparative analysis of gridded datasets and gauge measurements of rainfall in the Niger Delta region of Nigeria. Res J Environ Sci 8(7):373-390

Okoro UK, Chen W, Nath D, Nnamchi HC (2019) Variability and trends of atmospheric moisture in recent West African monsoon season and the Coordinated Regional Downscaling ExperimentAfrica projected 21st-century scenarios. Int J Climatol. https:// doi.org/10.1002/joc.6261

Ongena A, Dokme CH, Lika CSO, Budaka ST, Ykioglua GK, Dokme Cib I (2008) Copper and cadmium contents in ground and surface water in Corlu, Turkey. J Environ Prot Ecol 9(4):753-762

Onyeagocha AC (1980) Petrography and depositional environment of the Benin Formation Nigeria. J Minl Geol 17:147-158

Opara AI, Ibe FC, Alinnor NPC, JI, Enenebeaku CK, (2016) Geospatial and geostatistical analyses of particulate matter $\left(\mathrm{PM}_{10}\right)$ concentrations in Imo State, Nigeria. Int Lett Nat Sci 57:89-107

Pat-Mbano EC, Alaka IN, Okeoma IO, Onuoha TN (2010) Potable water supply in Owerri Metropolis: a challenge to MDGS achievements. Int J Dev Manag Rev 5(1):160-172

Pradeep JK (1998) Hydrogeology and quality of groundwater around Hirapur, District Sagar (M.P.). Pollut Res 17(1):91-94 
Ramakrishnaiah CR, Sadashivaiah C, Ranganna G (2009) Assessment of water quality index for the groundwater in Tumkur Taluk, Karnataka State, India. E-J Chem 6(2):523-530

Ramana KV, Singh L (2000) Microbial degradation of organic wastes at low temperatures. Def Sci J 50(4):371-382

Rodriguez MC, Barsanti L, Passarelli V, Evangelista V, Conforti V, Gualtieri P (2007) Effects of chromium on photosynthetic and photoreceptive apparatus of the alga Chlamydomonas Reinhardtii. Environ Res 105(2):234-239

Rondeau V, Commenges D, Jacqmin-Gadda H, Dartigues JF (2000) Relation between aluminium concentrations in drinking water and Alzheimer's disease: an 8-year follow-up study. Am J Epidemiol 152:59-66

Rubiat I, Shaikh MdF, Md Ruhul A, Farha MJ, Mohammod JI, Md Jahangir A, Mohammad NH, Mohammad A (2017) Assessment of $\mathrm{pH}$ and total dissolved substances (TDS) in the commercially available bottled drinking water. IOSR J Nurs Health Sci 6(5):35-40 (Ver IX)

Sane MR, Malukani K, Kulkarni R, Varun A (2018) Fatal iron toxicity in an adult: clinical profile and review. Indian J Crit Care Med 22(11):801-803

Singh KP, Singh VK, Malik A, Basant N (2006) Distribution of nitrogen species in groundwater aquifers of an industrial area in alluvial Indo-Gangetic plains-a case study. Environ Geochem Health 28:473-485

Singh AL, Tripathi AK, Kumar A, Singh VK (2012) Nitrate and phosphate contamination in the groundwater of Varanasi, Uttar Pradesh. India J Ind Res Technol 2(1):26-32

Smith AH, Lingas EO, Rahman M (2000) Contamination of drinkingwater by arsenic in Bangladesh: a public health emergency. Bull World Health Organ, World Health Organ 78(9):1093-1103

Srinivasan PT, Viraraghavan T (2002) Characterisation and concentration profile of aluminium during drinking-water treatment. Water SA 28(1):99-106

Su GLS (2008) Assessing the effect of a dumpsite to groundwater quality in Payatas, Philippines. Am J Environ Sci 4:276-280

Sun W, Wang J, Li Z, Yao X, Yu J (2014) Influences of climate change on water resources availability in Jinjiang Basin. China. Sci World J 2014:908349. https://doi.org/10.1155/2014/908349

Taylor R, Allen A (2006) World Health Organization. In: Schmoll O, Howard G, Chilton J, ChorusI (eds) Protecting groundwater for health: managing the quality of drinking-water sources. IWA Publishing, London, pp 339-362

Tay C, Kortatsi B (2008) Groundwater Quality Studies: A Case Study of the Densu Basin, Ghana. West Afr J Appl Ecol 12:1-18

Temilola O, Oluwatoyin A, Emmanuel A (2014) Impact assessment of dumpsites on quality of near-by soil and underground water: a case study of an abandoned and a functional dumpsite in Lagos, Nigeria. Int J Sci, Environ, Technol 3(3):1004-1101

Teta C, Hikwa T (2017) Heavy metal contamination of groundwater from an unlined landfill in Bulawayo, Zimbabwe. J Health Pollut 7(15):18-27
Tukura MI, Ayinya G, Ibrahim IG, Onche EU (2014) Assessment of Heavy Metals in Ground Water from Nasarawa State, Middle Belt, Nigeria. Am Chem Sci J 4:798-812

Uma KO (1989) An appraisal of the groundwater resources of the Imo River Basin, Nigerian. J Miner Geol 25(1 \& 2):305-315

USEPA (2010) Risk-based concentration table. United States Environmental Protection Agency. http://www.epa.gov/reg3hwmd/risk/ human/index.htm. Accessed 26 Sept 2019

USEPA (1989) Risk assessment guidance for superfund, vol 1, human health evaluation manual (part A). Report EPA/540/1-89/002, United States Environmental Protection Agency, Washington, DC

Valko M, Morris H, Cronin MTD (2005) Metals, toxicity, and oxidative stress. Curr Med Chem 12(10):1161-1208

Vincent KN, Ebenezer KH, Smile KA (2012) Assessment of the impact of solid waste dumpsites on some surface water systems in the accra metropolitan area, Ghana. J Water Resour Prot 4:605-615

Vrijheid M (2000) Health effects of residence near hazardous waste landfill sites: A review of epidemiologic literature. Environ Health Perspect 108:101-112

Water Stewardship Information Series (2007) Iron and manganese in groundwater. https://www.rdn.bc.ca/cms/wpattachments/wpID2 284atID3808.pdf. Accessed 20 Aug 2019

WHO (2004a) World Health Organization Guidelines for drinking water recommendation, Genera, Switzerland, vol. 1. http://www. whqlibdocwho.Int/publications/2004/9241546387.pdf. Assessed 6 Oct 2019

WHO (2004b) Copper in drinking-water background document for development of WHO guidelines for drinking-water quality. https ://www.who.int/water_sanitation_health/dwq/chemicals/coppe r.pdf. Accessed 26 Sept 2019

WHO/UNICEF (2000). Global water supply and sanitation assessment report. World Health Organization, Geneva. https://www.who. int/water_sanitation_health/monitoring/jmp2000.pdf. Accessed 25 Sept 2019

WHO (2011) Manganese in drinking-water. http://www.who.int/water _sanitation_health/dwq/chemicals/manganese.pdf. Accessed 25 Sept 2019

Wu B, Zhao DY, Jia HY, Zhang Y, Zhang XX, Cheng SP (2009) Preliminary risk assessment of trace metal pollution in surface water from Yangtze River in Nanjing Section, China. Bull Environ Contam Toxicol 82(4):405-409

Zhao DYB, Jia HY, Zhang Y, Zhang XX, Cheng SP (2009) Preliminary risk assessment of trace metal pollution in surface water from Yangtze River in Nanjing section, China. Bull Environ Contam Toxicol 82:405-409

Publisher's Note Springer Nature remains neutral with regard to jurisdictional claims in published maps and institutional affiliations. 